\title{
Studies on the Mechanical Properties of Dry, Saturated, and Frozen Marls Using Destructive and Non-destructive Laboratory Approaches
}

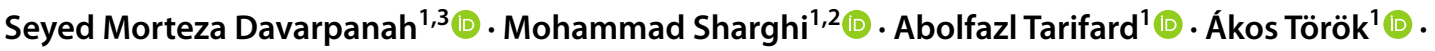 \\ Balázs Vásárhelyi ${ }^{1}$ [1]
}

Received: 8 October 2020 / Accepted: 16 June 2021 / Published online: 25 June 2021

(c) The Author(s) 2021

\begin{abstract}
The mechanical properties of frozen rocks vary significantly from the properties of the same lithology under ambient temperature. The goal of this paper is to investigate these changes in the physical and mechanical properties of rocks due to saturation and freezing. Besides, the attention was paid on discovering new correlations between the mechanical characteristics. To fulfill these objectives, 36 uniaxial compressive strength tests, 36 Brazilian splitting tests, and 48 point load tests were carried out. The samples were tested in air dry, water saturated, and frozen $\left(-20^{\circ} \mathrm{C}\right)$ conditions. The measured physical and mechanical parameters were analyzed by using regression analyses. It was found that the average uniaxial compressive strength of frozen samples $(21.93 \mathrm{MPa})$ is $86.4 \%$ more than saturated ones $(11.76 \mathrm{MPa})$ but $25.9 \%$ less than dry specimens $(29.62 \mathrm{MPa})$. Additionally, high correlations were established between uniaxial compressive strength and $I_{\mathrm{S}}(50)$ under airdry, saturated, and frozen conditions for the investigated marl samples. Furthermore, it is of particular interest to observe a high correlation with the determination coefficient $\left(R^{2}=0.95\right)$ between the constants of previously published linear regressions of UCS- $I_{\mathrm{s}}(50)$ under dry status.
\end{abstract}

Keywords Uniaxial compressive strength · Tensile strength · Point load test · Ultrasonic wave velocity · Marl

\section{List of Symbols}

$\mathrm{UCS}\left(\sigma_{\mathrm{c}}\right) \quad$ Uniaxial compressive strength $(\mathrm{MPa})$

TS $\left(\sigma_{\mathrm{t}}\right) \quad$ Tensile strength (MPa)

P LT Point load test

$V_{\mathrm{P}} \quad$ Ultrasonic wave velocity $\left(\frac{\mathrm{km}}{\mathrm{s}}\right)$

$M_{\mathrm{R}} \quad$ Modulus ratio

$I_{\mathrm{S}} \quad$ Point load strength index

De $\quad$ Equivalent diameter $(\mathrm{mm})$

$P \quad$ Failure load $(\mathrm{kN})$

$\rho \quad \operatorname{Density}\left(\frac{\mathrm{g}}{\mathrm{cm}^{3}}\right)$

Seyed Morteza Davarpanah

morteza.davarpanah@emk.bme.hu

1 Department of Engineering Geology and Geotechnics, Budapest University of Technology and Economics, Budapest, Hungary

2 Department of Mining Engineering, Sahand University of Technology, 0600 Tabriz, Iran

3 Faculty of Civil Engineering, Department of Engineering Geology and Geotechnics, Budapest University of Technology and Economics, Budapest 1111, Hungary

$\begin{array}{ll}\varepsilon & \text { Strain (\%) } \\ E & \text { Modulus of elasticity (GPa }\end{array}$

\section{Introduction}

The use of ground freezing to provide excavation support and groundwater control in weak rock mass conditions has been extensively addressed in different parts of the world. Numerous mining and civil projects use artificial freezing worldwide; however, uncertainties remain concerning understanding and predicting the behavior of frozen rocks. Several research addresses the impact of water on the strength of soft rocks (Mellor 1971, 1973; Vásárhelyi 2005; Vásárhelyi and Ván 2006; Miščević and Vlastelica 2011; Wong et al. 2016; Vásárhelyi and Davarpanah 2018; Vlastelica et al. 2018; Li et al. 2020; Bar and Barton 2021). However, there is limited research on the effect of freezing on the mechanical properties of intact rock and rock mass (Jamshid 2019; Jamshidi et al. 2018; Kodama et al. 2013; Yagiz 2019). Mellor (1971, 1973) measured the uniaxial compressive strength (UCS) and tensile strength (TS) of water saturated, and air dry granite, limestone, and sandstone rock core from temperatures of 


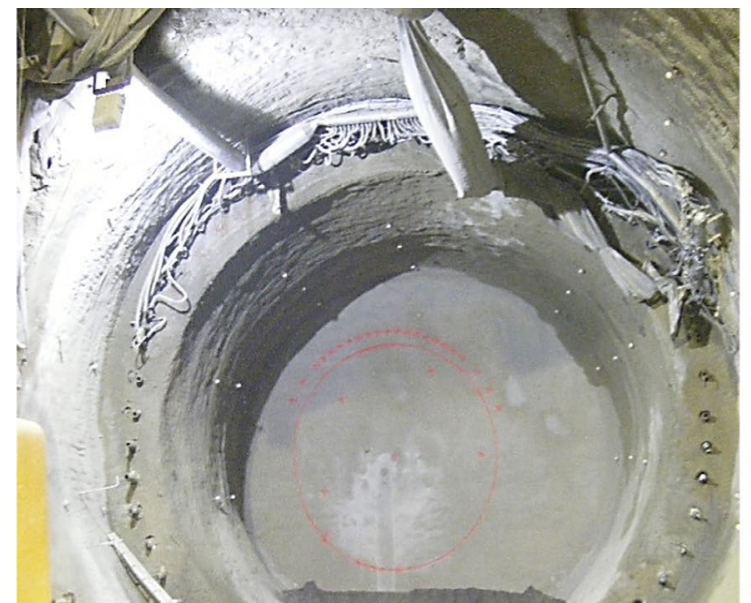

(a)

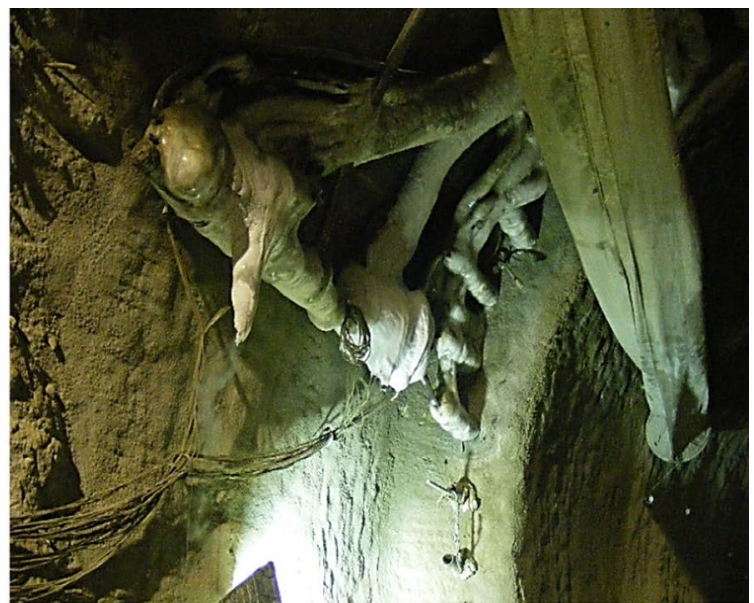

(b)

Fig. 1 Freezing technique to provide excavation support for the tunnel (Metro Line 4-Budapest)

Fig. 2 Laboratory samples of marl

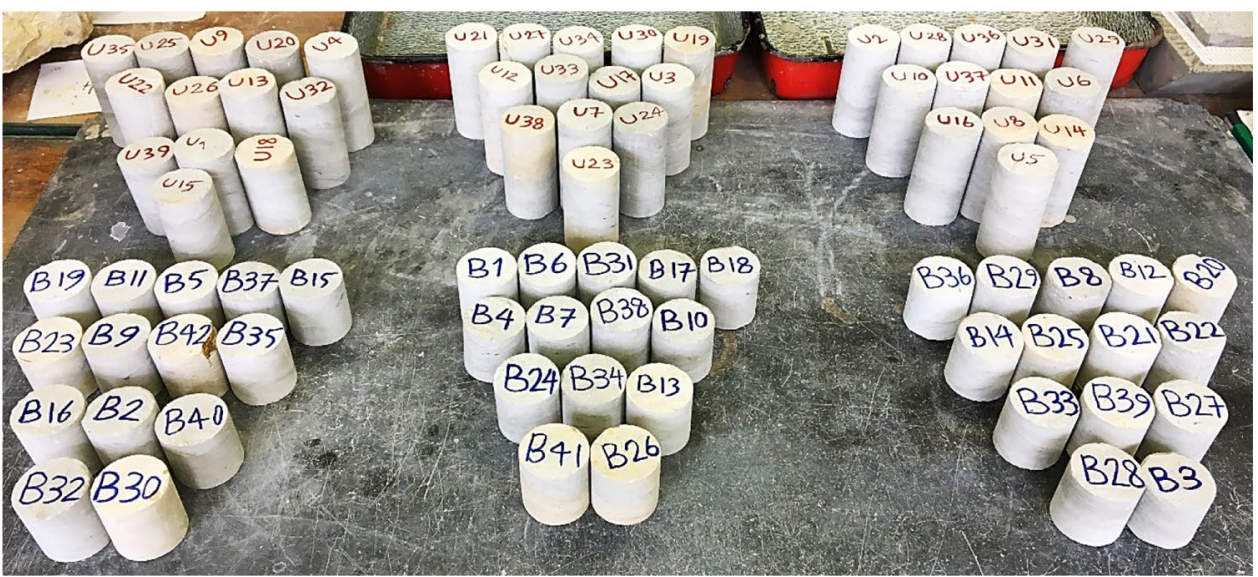

25 to $-195{ }^{\circ} \mathrm{C}$ and observed that the compressive strengths increase with decreasing temperature. Roworth (2005) carried out a series of UCS tests on three different kinds of rocks (hematized sandstone, bleached sandstone, and metapelite basement). Based on his observations, there was a significant gain in strength due to freezing.

Miščević and Vlastelica (2011) carried out a study to discuss and identify the physical properties that can be used in addition to the slake durability index. Samples were subjected to 4 cycles of slake durability, point load tests, and tests to determine dry density, carbonate content, and absorption of water. The results of this study obtained from a limited number of marls from the region of Dalmatia in Croatia. The scatter of data suggests that strength probably has no influence on the durability of marls. In addition, Vlastelica et al. (2018) determined the additional criteria or modifications of the standardized durability testing procedures for reducing the uncertainties identified in the assessment of the durability of marl, or disadvantages of their application

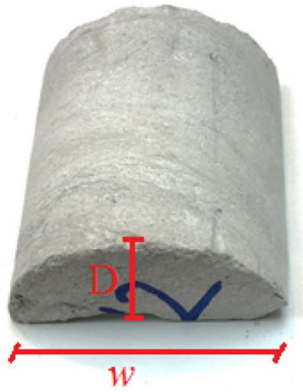

(a)

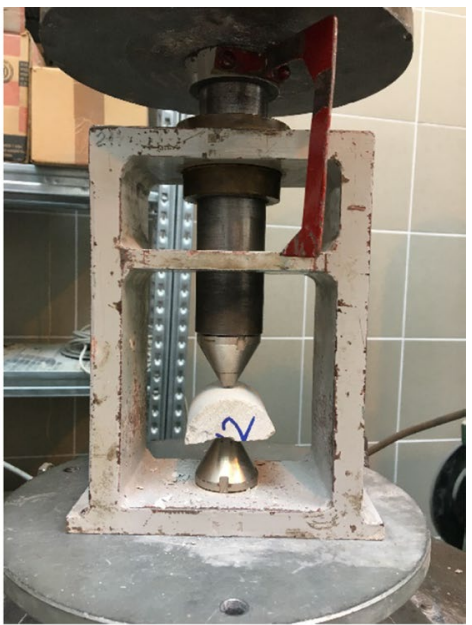

(b)
Fig. 3 a Half cut broken sample after tensile strength test. b A typical point load test of the sample 
Table 2 Mechanical properties of dry Brazilian test samples

\begin{tabular}{llll}
\hline Sample number & $\rho_{\mathrm{d}}\left(\frac{\mathrm{g}}{\mathrm{cm}^{3}}\right)$ & $\sigma_{\mathrm{t}(\mathrm{d})}(\mathrm{MPa})$ & $V_{\mathrm{P}(\mathrm{d})}\left(\frac{\mathrm{km}}{\mathrm{s}}\right)$ \\
\hline B3 & 2.40 & 4.20 & 1.75 \\
B8 & 2.47 & 3.05 & 2.31 \\
B12 & 2.40 & 6.22 & 2.71 \\
B14 & 2.44 & 6.29 & 2.53 \\
B20 & 2.42 & 3.47 & 2.65 \\
B21 & 2.36 & 4.39 & 2.75 \\
B22 & 2.40 & 5.28 & 1.76 \\
B25 & 2.40 & 4.83 & 2.51 \\
B27 & 2.33 & 3.43 & 1.69 \\
B28 & 4.25 & 1.97 \\
B29 & 2.44 & 5.51 & 2.56 \\
B33 & 2.46 & 6.02 & 2.45 \\
B36 & 2.42 & 4.69 & 3.01 \\
B39 & 2.45 & 3.49 & 2.32 \\
\hline
\end{tabular}

in studies of soft rocks such as erosion of cuts and settlement of embankments caused by deterioration of soft rock grains.

In the paper published by Török et al. (2018), the relationship between mechanical and physical properties of two types of highly porous rocks, such as Oolitic Miocene limestone and Miocene rhyolite tuff, was compared. The research gets to the conclusion that the strength of frozen, dry and saturated porous rocks are relatively low, but when the rocks are frozen, very high uniaxial strength values are measured. It can be interpreted that the strength of frozen rocks is related not only to the mineral composition of rock itself but also to the formation of pore ice. Kodama et al. (2019) investigated the long term behavior of Shikotsu welded tuff at subzero temperatures. The results illustrated that the UCS of frozen wet specimens were greater than those of the frozen dry specimens. Jia et al. (2020) investigated the influence of the initial water content on the mechanical properties of frozen argillaceous siltstone (at $-20{ }^{\circ} \mathrm{C}$ ). Both strengths (UCS, TS, and point-load strength) and deformability of frozen argillaceous siltstone increased. The pore ice formed not only fills pore space in rock but also enhances the cementation of mineral particles (Liu et al. 2018). In other similar work published by Liu et al. (2020), it was found that crack initiation stress and crack damage stress increased due to freezing in sandstone and mudstone. The reason is that the existence of pore ice reduces stress concentration around a crack and enhances the cementation of mineral particles. Therefore, peak stresses of sandstone and mudstone increase linearly with the decrease of freezing temperature.

Similarly, in the paper published by Davarpanah et al. (2019), the relationship between different mechanical properties of highly porous limestone in case of dry, water saturated, and frozen conditions $\left(-20^{\circ} \mathrm{C}\right)$ was investigated. It was found that the mechanical behavior of the frozen rock is
Table 1 Mechanical properties of dry UCS test samples

\begin{tabular}{llllllll}
\hline Sample number & $\rho_{\mathrm{d}}\left(\frac{\mathrm{g}}{\mathrm{cm}^{3}}\right)$ & $E_{\mathrm{d}}(\mathrm{GPa})$ & $\sigma_{\mathrm{c}(\mathrm{d})}(\mathrm{MPa})$ & $\varepsilon_{\mathrm{amax}(\mathrm{d})}(\%)$ & $M_{\mathrm{R}(\mathrm{d})}$ & $V_{\mathrm{P}(\mathrm{d})}\left(\frac{\mathrm{km}}{\mathrm{s}}\right)$ & $\left(\sigma_{\mathrm{c}(\mathrm{d})} / \sigma_{\mathrm{t}(\mathrm{d})}\right)$ \\
\hline $\mathrm{U} 10$ & 2.47 & 6.20 & 28.17 & 1.26 & 220.11 & 2.83 & 6.71 \\
$\mathrm{U} 11$ & 2.40 & 3.30 & 29.51 & 0.96 & 111.83 & 2.67 & 9.69 \\
$\mathrm{U} 14$ & 2.42 & 3.76 & 35.39 & 1.26 & 106.25 & 2.55 & 5.69 \\
$\mathrm{U} 16$ & 2.41 & 3.60 & 28.80 & 1.31 & 125.01 & 2.29 & 4.58 \\
$\mathrm{U} 2$ & 2.47 & 8.60 & 37.52 & 0.89 & 229.20 & 3.41 & 10.82 \\
$\mathrm{U} 28$ & 2.44 & 4.10 & 35.62 & 0.63 & 115.09 & 3.27 & 8.11 \\
$\mathrm{U} 29$ & 2.44 & 4.40 & 27.15 & 0.78 & 162.04 & 2.86 & 5.14 \\
$\mathrm{U} 31$ & 2.37 & 2.65 & 23.58 & 1.00 & 112.40 & 2.33 & 4.88 \\
$\mathrm{U} 36$ & 2.43 & 1.63 & 26.56 & 0.91 & 61.37 & 3.35 & 8.04 \\
$\mathrm{U} 37$ & 2.40 & 1.97 & 28.48 & 0.99 & 69.17 & 3.47 & 6.7 \\
$\mathrm{U} 5$ & 2.35 & 3.88 & 27.55 & 0.94 & 140.82 & 2.33 & 5.00 \\
$\mathrm{U} 6$ & 2.42 & 1.82 & 27.14 & 1.72 & 67.05 & 2.12 & 4.51 \\
\hline
\end{tabular}


Table 3 Statistical analysis of UCS of dry samples

Table 4 Mechanical properties of saturated UCS test samples

Table 5 Mechanical properties of saturated Brazilian test samples

Table 6 Statistical analysis of UCS of saturated samples

\begin{tabular}{llllllllr}
\hline & $\rho_{\mathrm{d}}\left(\frac{\mathrm{g}}{\mathrm{cm}^{3}}\right)$ & $E_{\mathrm{d}}(\mathrm{GPa})$ & $\sigma_{\mathrm{c}(\mathrm{d})}(\mathrm{MPa})$ & $\sigma_{\mathrm{t}(\mathrm{d})}(\mathrm{MPa})$ & $\varepsilon_{\mathrm{amax}(\mathrm{d})}(\%)$ & $M_{\mathrm{R}(\mathrm{d})}$ & $V_{\mathrm{P}(\mathrm{d})}\left(\frac{\mathrm{km}}{\mathrm{s}}\right)$ & $\left(\sigma_{\mathrm{c}(\mathrm{d})} / \sigma_{\mathrm{t}(\mathrm{d})}\right)$ \\
\hline Min & 2.35 & 1.63 & 23.58 & 3.05 & 0.63 & 61.37 & 2.12 & 4.51 \\
Max & 2.47 & 8.6 & 37.52 & 6.29 & 1.72 & 229.2 & 3.47 & 10.82 \\
Average & 2.42 & 3.83 & 29.62 & 4.75 & 1.05 & 126.7 & 2.79 & 6.66 \\
SD & 0.03 & 1.89 & 4.06 & 1.08 & 0.28 & 52.28 & 0.46 & 2.01 \\
\hline
\end{tabular}

\begin{tabular}{lllclccc}
\hline Sample number & $\rho_{\mathrm{s}}\left(\frac{\mathrm{g}}{\mathrm{cm}^{3}}\right)$ & $E_{\mathrm{s}}(\mathrm{GPa})$ & $\sigma_{\mathrm{c}(\mathrm{s})}(\mathrm{MPa})$ & $\varepsilon_{\mathrm{amax}(\mathrm{s})}(\%)$ & $M_{\mathrm{R}(\mathrm{s})}$ & $V_{\mathrm{P}(\mathrm{s})}\left(\frac{\mathrm{km}}{\mathrm{s}}\right)$ & $\left(\sigma_{\mathrm{c}(\mathrm{s})} / \sigma_{\mathrm{t}(\mathrm{s})}\right)$ \\
\hline $\mathrm{U} 12$ & 2.51 & 4.52 & 19.5 & 1.07 & 231.8 & 3.84 & 6.42 \\
$\mathrm{U} 19$ & 2.50 & 0.7 & 7.41 & 1.29 & 94.52 & 2.34 & 9.32 \\
$\mathrm{U} 21$ & 2.54 & 3.7 & 15.08 & 0.25 & 245.35 & 4.04 & 5.09 \\
U23 & 2.51 & 4.08 & 17.17 & 0.57 & 237.56 & 3.31 & 0.57 \\
U27 & 2.54 & 1.95 & 5.84 & 0.41 & 333.93 & 3.73 & 2.94 \\
U3 & 2.54 & 1.43 & 9.85 & 0.86 & 145.22 & 2.62 & 8.79 \\
U30 & 2.52 & 3.14 & 18.35 & 0.77 & 171.16 & 3.61 & 14.46 \\
U33 & 2.55 & 1.17 & 9.58 & 0.92 & 122.15 & 3 & 8.46 \\
U34 & 2.51 & 3.5 & 14.36 & 0.3 & 243.73 & 3.8 & 7.81 \\
U38 & 2.49 & 1.13 & 6.61 & 0.62 & 171.01 & 2.06 & 7.52 \\
U7 & 2.52 & 0.63 & 4.64 & 0.8 & 135.7 & 2.41 & 2.79 \\
\hline
\end{tabular}

\begin{tabular}{llll}
\hline Sample number & $\rho_{\mathrm{d}}\left(\frac{\mathrm{g}}{\mathrm{cm}^{3}}\right)$ & $\sigma_{\mathrm{t}(\mathrm{s})}(\mathrm{MPa})$ & $V_{\mathrm{P}(\mathrm{d})}\left(\frac{\mathrm{km}}{\mathrm{s}}\right)$ \\
\hline B1 & 2.51 & 3.04 & 3.96 \\
B4 & 2.45 & 0.79 & 2.95 \\
B6 & 2.44 & 3.04 & 3.33 \\
B7 & 2.44 & 1.19 & 3.02 \\
B10 & 2.43 & 1.99 & 2.56 \\
B3 & 2.37 & 1.12 & 2.79 \\
B17 & 2.46 & 1.27 & 2.88 \\
B18 & 2.43 & 1.13 & 2.79 \\
B24 & 2.43 & 1.08 & 2.71 \\
B26 & 2.32 & 0.88 & 2 \\
B31 & 1.66 & 3 \\
B34 & 2.46 & 1.10 & 2.76 \\
B38 & 2.42 & 1.72 & 3.13 \\
B41 & 2.47 & 1.29 & 2.59 \\
\hline
\end{tabular}

\begin{tabular}{lllllllll}
\hline & $\rho_{\mathrm{s}}\left(\frac{\mathrm{g}}{\mathrm{cm}^{3}}\right)$ & $E_{\mathrm{s}}(\mathrm{GPa})$ & $\sigma_{\mathrm{c}(\mathrm{s})}(\mathrm{MPa})$ & $\sigma_{\mathrm{t}(\mathrm{s})}(\mathrm{MPa})$ & $\varepsilon_{\mathrm{amax}(\mathrm{s})}(\%)$ & $M_{\mathrm{R}(\mathrm{s})}$ & $V_{\mathrm{P}(\mathrm{s})}\left(\frac{\mathrm{km}}{\mathrm{s}}\right)$ & $\left(\sigma_{\mathrm{c}(\mathrm{s})} / \sigma_{\mathrm{t}(\mathrm{s})}\right)$ \\
\hline Min & 2.49 & 0.63 & 4.64 & 0.79 & 0.25 & 94.52 & 2.06 & 0.57 \\
Max & 2.55 & 4.52 & 19.5 & 3.04 & 1.29 & 333.93 & 4.04 & 14.46 \\
Average & 2.52 & 2.36 & 11.76 & 1.56 & 0.71 & 193.83 & 3.16 & 6.74 \\
SD & 0.02 & 1.36 & 5.13 & 0.77 & 0.31 & 67.35 & 0.67 & 3.64 \\
\hline
\end{tabular}


Table 7 Mechanical properties of frozen UCS test samples

\begin{tabular}{llrllrrr}
\hline Sample number & $\rho_{\mathrm{f}}\left(\frac{\mathrm{g}}{\mathrm{cm}^{3}}\right)$ & $E_{\mathrm{f}}(\mathrm{GPa})$ & $\sigma_{\mathrm{c}(\mathrm{f})}(\mathrm{MPa})$ & $\varepsilon_{\mathrm{amax}(\mathrm{f})}(\%)$ & \multicolumn{1}{c}{$M_{\mathrm{R}(\mathrm{f})}$} & $V_{\mathrm{P}(\mathrm{f})}\left(\frac{\mathrm{km}}{\mathrm{s}}\right)$ & $\left(\sigma_{\mathrm{c}(\mathrm{f})} / \sigma_{\mathrm{t}(\mathrm{f})}\right)$ \\
\hline U1 & 2.52 & 4.96 & 22.71 & 1.03 & 218.37 & 4.72 & 5.43 \\
U13 & 2.50 & 12.70 & 40.65 & 0.61 & 312.44 & 4.94 & 14.37 \\
U15 & 2.51 & 0.64 & 14.61 & 2.47 & 43.80 & 3.34 & 1.79 \\
U18 & 2.49 & 2.41 & 20.13 & 1.68 & 119.74 & 4.39 & 4.35 \\
U20 & 2.59 & 2.30 & 24.40 & 0.85 & 94.28 & 4.88 & 9.54 \\
U22 & 2.47 & 2.37 & 14.81 & 0.79 & 160.03 & 4.76 & 2.69 \\
U25 & 2.54 & 1.51 & 19.31 & 1.66 & 78.19 & 4.60 & 2.58 \\
U26 & 2.46 & 2.20 & 23.51 & 1.02 & 93.56 & 4.56 & 6.23 \\
U32 & 2.55 & 1.34 & 30.94 & 0.82 & 43.31 & 4.22 & 4.30 \\
U35 & 2.51 & 0.64 & 9.90 & 1.43 & 64.67 & 3.42 & 1.40 \\
U39 & 2.54 & 0.84 & 23.41 & 2.57 & 35.89 & 4.49 & 6.02 \\
U4 & 2.52 & 2.75 & 25.47 & 1.04 & 107.97 & 4.53 & 6.35 \\
U9 & 2.47 & 0.94 & 15.30 & 1.81 & 61.42 & 4.17 & 4.44 \\
\hline
\end{tabular}

Table 8 Mechanical properties of frozen Brazilian test samples

\begin{tabular}{llll}
\hline Sample number & $\rho_{\mathrm{f}}\left(\frac{\mathrm{g}}{\mathrm{cm}^{3}}\right)$ & $\sigma_{\mathrm{t}(\mathrm{f})}(\mathrm{MPa})$ & $V_{\mathrm{P}(\mathrm{f})}\left(\frac{\mathrm{km}}{\mathrm{s}}\right)$ \\
\hline B2 & 2.52 & 4.18 & 4.25 \\
B5 & 2.50 & 2.83 & 4.94 \\
B9 & 2.51 & 8.17 & 4.57 \\
B11 & 2.49 & 4.63 & 4.69 \\
B15 & 2.59 & 2.56 & 3.92 \\
B16 & 2.47 & 5.51 & 4.17 \\
B19 & 2.54 & 7.47 & 5.15 \\
B23 & 2.46 & 3.78 & 4.72 \\
B30 & 2.55 & 7.19 & 4.46 \\
B32 & 7.09 & 3.83 \\
B35 & 2.51 & 3.89 & 4.35 \\
B37 & 2.54 & 4.01 & 3.55 \\
B40 & 2.52 & 3.45 & 3.34 \\
B42 & 2.47 & 3.69 & 4.76 \\
\hline
\end{tabular}

\begin{tabular}{llcclllll}
\hline & $\rho_{\mathrm{f}}\left(\frac{\mathrm{g}}{\mathrm{cm}^{3}}\right)$ & $E_{\mathrm{f}}(\mathrm{GPa})$ & $\sigma_{\mathrm{c}(\mathrm{f})}(\mathrm{MPa})$ & $\sigma_{\mathrm{t}(\mathrm{f})}(\mathrm{MPa})$ & $\varepsilon_{\mathrm{amax}(\mathrm{f})}(\%)$ & $M_{\mathrm{R}(\mathrm{f})}$ & $V_{\mathrm{P}(\mathrm{f})}\left(\frac{\mathrm{km}}{\mathrm{s}}\right)$ & $\left(\sigma_{\mathrm{c}(\mathrm{f})} / \sigma_{\mathrm{t}(\mathrm{f})}\right)$ \\
\hline Min & 2.46 & 0.64 & 9.9 & 2.56 & 0.61 & 35.89 & 3.34 & 1.4 \\
Max & 2.59 & 12.7 & 40.65 & 8.17 & 2.57 & 312.44 & 4.94 & 14.37 \\
Average & 2.51 & 2.74 & 21.93 & 4.98 & 1.37 & 110.28 & 4.39 & 5.35 \\
$\mathrm{SD}$ & 0.04 & 3.09 & 7.64 & 1.82 & 0.61 & 76.26 & 0.48 & 3.36 \\
\hline
\end{tabular}

remarkably different from saturated and air-dry specimens, having higher strength and modulus of elasticity. Maoyan et al. (2020) performed a series of triaxial tests on western Jurassic sandstone. They observed a sharp increase in mechanical properties such as peak strength, cohesion, internal friction angle, residual strength, and elasticity modulus increased with the decreasing temperature. In uniaxial compression tests, the pore ice formed can effectively bear a partial load. Therefore, the strength of frozen rock increases with the decrease of temperature.

The goal of the current paper is to investigate the changes in physical and mechanical properties of marl under dry, saturated, and frozen conditions and provide new information on correlations between uniaxial compressive strength 


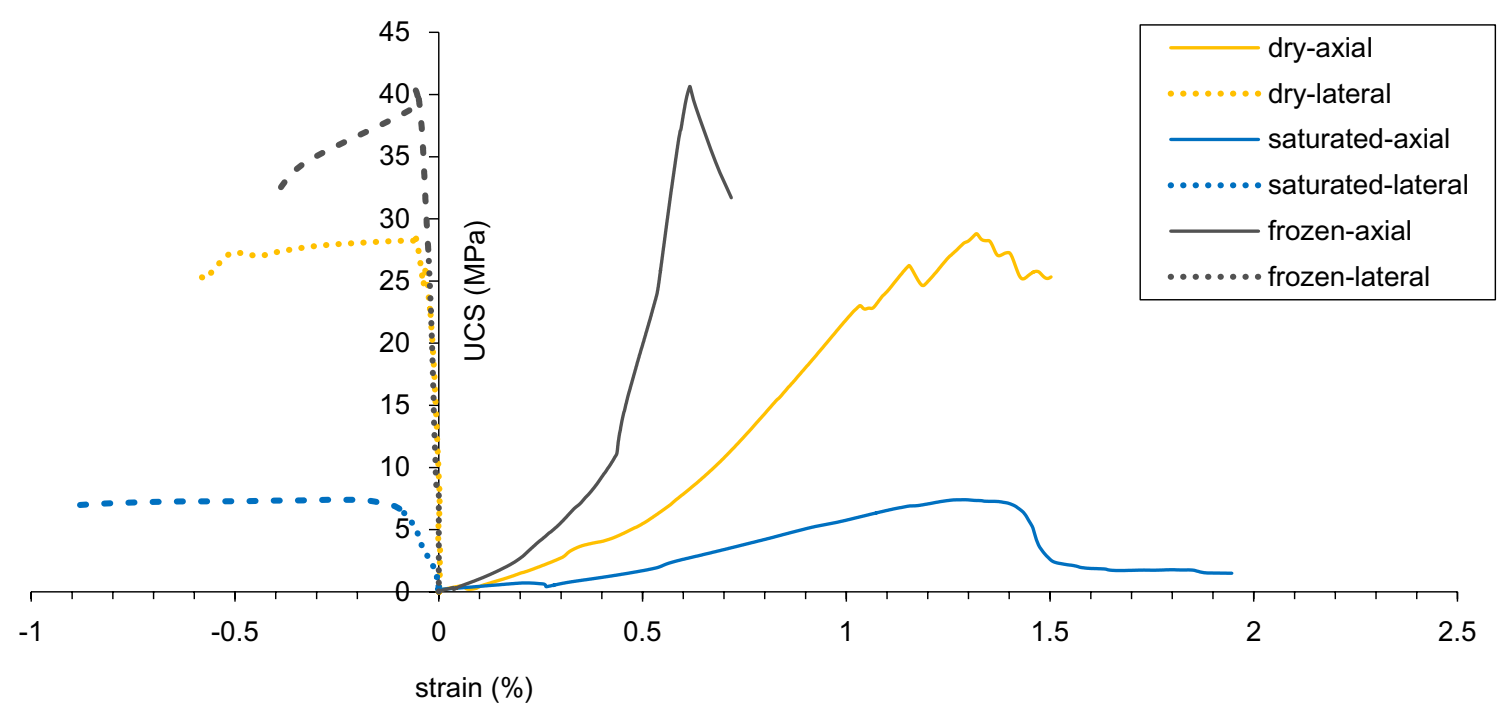

Fig. 4 Typical stress-strain curve under dry, saturated, and frozen conditions

Table 10 Summary of point load test results of dry samples

\begin{tabular}{llllllll}
\hline Sample number & $D(\mathrm{~mm})$ & $w(\mathrm{~mm})$ & De $(\mathrm{mm})$ & $P(\mathrm{kN})$ & $F$ & $I_{\mathrm{S}(\mathrm{d})}$ & $I_{\mathrm{S}}(50)_{(\mathrm{d})}$ \\
\hline B25-1 & 27.89 & 49.67 & 42.01 & 3.09 & 0.92 & 1.75 & 1.62 \\
B25-2 & 22.82 & 48.92 & 37.71 & 2.12 & 0.88 & 1.49 & 1.31 \\
B14-1 & 24.08 & 48.56 & 38.60 & 2.03 & 0.89 & 1.36 & 1.21 \\
B33-1 & 27.37 & 49.2 & 41.42 & 1.21 & 0.92 & 0.71 & 0.65 \\
B39-1 & 30.21 & 50.27 & 43.98 & 2.47 & 0.94 & 1.28 & 1.21 \\
B14-3 & 23.24 & 48.43 & 37.87 & 3.43 & 0.88 & 2.39 & 2.11 \\
B12-1 & 26.08 & 48.74 & 40.24 & 1.24 & 0.91 & 0.76 & 0.69 \\
B12-2 & 23.01 & 47.47 & 37.30 & 3.34 & 0.88 & 2.40 & 2.10 \\
B21-1 & 18.78 & 48.3 & 33.99 & 1.85 & 0.84 & 1.60 & 1.34 \\
B21-2 & 26.2 & 47.11 & 39.65 & 1.83 & 0.90 & 1.17 & 1.05 \\
B29-1 & 29.59 & 49.31 & 43.11 & 4.85 & 0.94 & 2.61 & 2.44 \\
B29-2 & 20.49 & 48.47 & 35.57 & 2.50 & 0.86 & 1.97 & 1.69 \\
B36-1 & 23.74 & 48.38 & 38.25 & 6.02 & 0.89 & 4.12 & 3.65 \\
B36-2 & 23.65 & 48.43 & 38.20 & 4.06 & 0.89 & 2.78 & 2.46 \\
B28-1 & 19.4 & 48.41 & 34.59 & 1.43 & 0.85 & 1.19 & 1.01 \\
B28-2 & 23.31 & 49.01 & 38.15 & 2.72 & 0.89 & 1.87 & 1.66 \\
B20 & 31.33 & 49.3 & 44.36 & 3.98 & 0.95 & 2.02 & 1.92 \\
B31 & 28.18 & 49.1 & 41.98 & 0.93 & 0.92 & 0.53 & 0.49 \\
B22 & 20.57 & 47.54 & 35.29 & 1.15 & 0.85 & 0.92 & 0.79 \\
\hline
\end{tabular}

(UCS) $\left(\sigma_{\mathrm{c}}\right)$, tensile strength (TS) $\left(\sigma_{\mathrm{t}}\right)$, point load test (PLT), ultrasonic wave velocity $\left(V_{\mathrm{P}}\right)$, Modulus ratio $\left(M_{\mathrm{R}}\right)$, and the $\left(\sigma_{\mathrm{c}} / \sigma_{\mathrm{t}}\right)$ of studied rock samples.

\section{Materials and Methods}

Investigated marl specimens were taken from part of Budapest Metro Line 4, which passes under the Danube river. The mechanical behavior of the Buda Marl lies between those 
Table 11 Summary of point load test results of saturated samples

\begin{tabular}{llllllll}
\hline Sample number & $D(\mathrm{~mm})$ & $w(\mathrm{~mm})$ & De $(\mathrm{mm})$ & $P(\mathrm{kN})$ & $F$ & $I_{\mathrm{S}(\mathrm{s})}$ & $I_{\mathrm{S}}(50)_{(\mathrm{s})}$ \\
\hline B7-1 & 25.72 & 49.11 & 40.11 & 1.18 & 0.91 & 0.73 & 0.66 \\
B13-1 & 23.01 & 48.35 & 37.65 & 1.33 & 0.88 & 0.94 & 0.83 \\
B41-1 & 26.67 & 49.44 & 40.98 & 0.95 & 0.91 & 0.57 & 0.52 \\
B6-1 & 29.48 & 49.46 & 43.10 & 1.32 & 0.94 & 0.71 & 0.66 \\
B1-1 & 25.19 & 49.83 & 39.99 & 3.31 & 0.90 & 2.07 & 1.87 \\
B24-1 & 27.44 & 49.14 & 41.45 & 0.36 & 0.92 & 0.21 & 0.19 \\
B24-2 & 19.14 & 49.05 & 34.58 & 0.36 & 0.85 & 0.30 & 0.25 \\
B6-2 & 24.1 & 49.27 & 38.89 & 1.44 & 0.89 & 0.95 & 0.85 \\
B1-2 & 24.8 & 49.29 & 39.46 & 2.57 & 0.90 & 1.65 & 1.48 \\
B41-2 & 22.42 & 49.52 & 37.61 & 0.40 & 0.88 & 0.28 & 0.25 \\
\hline
\end{tabular}

Table 12 Summary of point load test results of frozen samples

\begin{tabular}{llllllll}
\hline Sample number & $D(\mathrm{~mm})$ & $w(\mathrm{~mm})$ & $D e(\mathrm{~mm})$ & $P(\mathrm{kN})$ & $F$ & $I_{\mathrm{S}(\mathrm{f})}$ & $I_{\mathrm{S}}(50)_{(\mathrm{f})}$ \\
\hline B32-1 & 26.08 & 49.44 & 40.53 & 4.39 & 0.91 & 2.67 & 2.43 \\
B32-2 & 22.58 & 49.29 & 37.65 & 2.44 & 0.88 & 1.72 & 1.51 \\
B16-1 & 27.85 & 49.05 & 41.72 & 3.34 & 0.92 & 1.92 & 1.77 \\
B11-1 & 23.78 & 48.87 & 38.48 & 5.17 & 0.89 & 3.49 & 3.10 \\
B11-2 & 21.65 & 48.64 & 36.63 & 6.41 & 0.87 & 4.78 & 4.15 \\
B42-1 & 22.53 & 49.09 & 37.54 & 4 & 0.88 & 2.84 & 2.50 \\
B42-2 & 23.23 & 49.07 & 38.11 & 6.81 & 0.88 & 4.69 & 4.15 \\
B15-1 & 22 & 47.39 & 36.44 & 3.91 & 0.87 & 2.94 & 2.55 \\
B15-2 & 27.51 & 47.67 & 40.87 & 5.03 & 0.91 & 3.01 & 2.75 \\
B30-1 & 28 & 49.25 & 41.91 & 1.2 & 0.92 & 0.68 & 0.63 \\
B30-2 & 24.44 & 48.56 & 38.88 & 1.97 & 0.89 & 1.30 & 1.16 \\
B35-1 & 25.46 & 48.35 & 39.60 & 0.64 & 0.90 & 0.41 & 0.37 \\
B35-2 & 24.67 & 48.59 & 39.08 & 2.44 & 0.90 & 1.60 & 1.43 \\
B9-1 & 22.01 & 48.7 & 36.95 & 4.12 & 0.87 & 3.02 & 2.63 \\
B9-2 & 27.69 & 49.32 & 41.71 & 6.87 & 0.92 & 3.95 & 3.64 \\
B23-1 & 24.94 & 48.03 & 39.06 & 5.81 & 0.89 & 3.81 & 3.41 \\
B23-2 & 23.52 & 48.6 & 38.16 & 5.65 & 0.89 & 3.88 & 3.44 \\
B19-1 & 20.87 & 48.81 & 36.02 & 4.55 & 0.86 & 3.51 & 3.03 \\
B19-2 & 23.93 & 49.3 & 38.77 & 5.26 & 0.89 & 3.50 & 3.12 \\
\hline
\end{tabular}

of rock and soil; it is, therefore, appropriate to define it as both weak rock and strong soil. Calcareous marl resembles a medium strong or strong rock, and marl behaves like a weak one. The detailed description of this material was published by Görög (2007). As shown in Fig. 1, the freezing technique was used to provide support during tunnel excavation. Therefore, it is essential to make an accurate estimate of the mechanical properties of frozen samples for designing a support system and analysis.

Several tests were carried out in the laboratory of the Department of Engineering Geology and Geotechnics of BME university on the calcareous type of Buda Marl formation. The laboratory tests included firstly non-destructive tests, such as the measurements of density and ultrasonic pulse wave velocities in different petrophysical states, and destructive tests such as uniaxial compressive strength (UCS), the tensile strength (TS) (using Brazilian test), and point load test (PLT).

To determine the mechanical properties of investigated rock samples 39 cylindrical marl samples were prepared (but three samples failed in the water saturation stage before the test), so 36 samples were available for the uniaxial compressive test from which 12 samples in dry condition, 11 samples in saturated condition and 13 samples in frozen condition were tested. The samples were between 49 and $49.72 \mathrm{~mm}$ 
Fig. 5 Uniaxial compressive strength of the marl as a function of density (dry, saturated, and frozen)

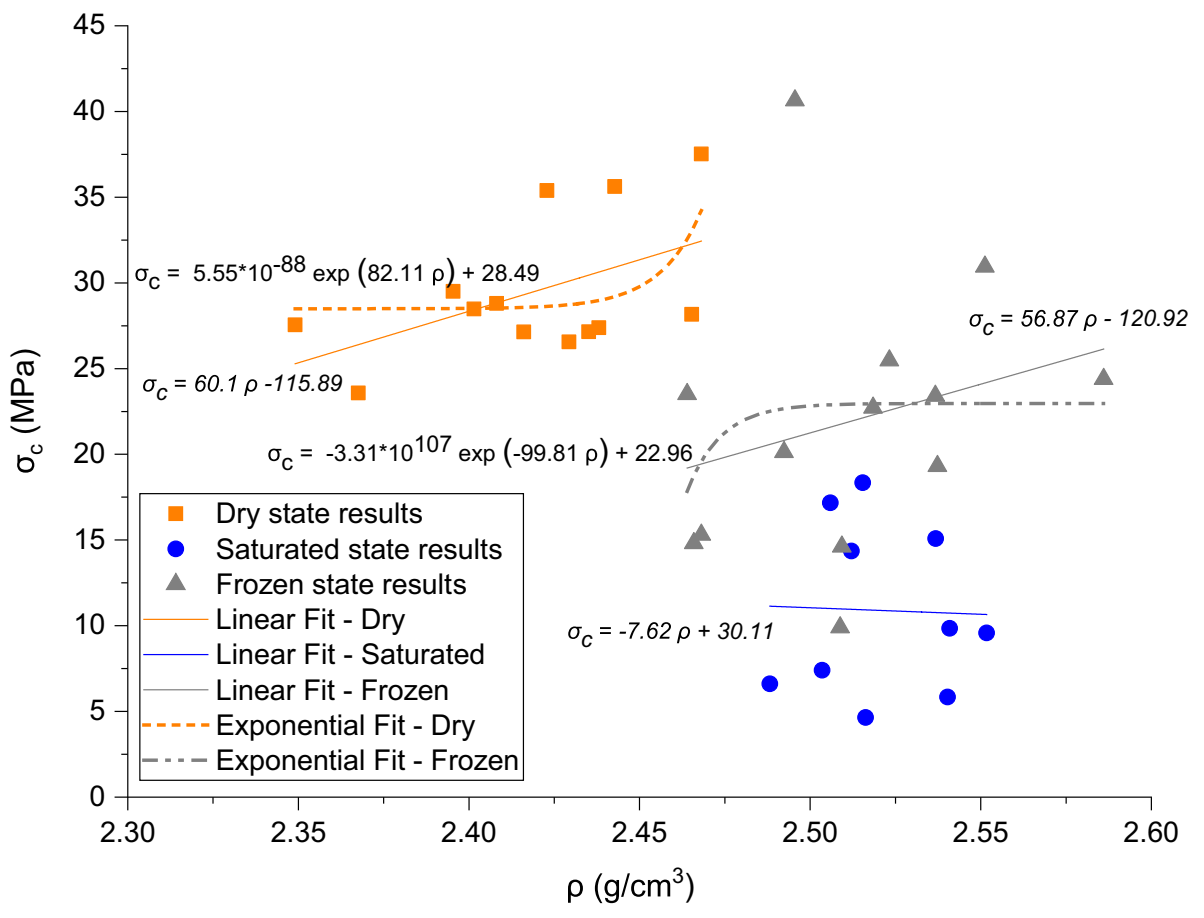

Table 13 Uniaxial compressive strength of marl as a function of density

\begin{tabular}{|c|c|c|c|c|c|c|c|}
\hline \multirow{3}{*}{$\begin{array}{l}\text { Fitting function } \\
\text { Equation } \\
\text { Parameters }\end{array}$} & \multicolumn{3}{|l|}{ Linear } & \multicolumn{4}{|c|}{ Exponential } \\
\hline & \multicolumn{3}{|c|}{$\sigma_{\mathrm{c}}=a \rho+b$} & \multicolumn{4}{|c|}{$\sigma_{\mathrm{c}}=\sigma_{\mathrm{c} 0}+A \exp \left(R_{0} \rho\right)$} \\
\hline & $a$ & $b$ & $R^{2}$ & $\sigma_{\mathrm{c} 0}$ & $A$ & $R_{0}$ & $R^{2}$ \\
\hline \multicolumn{8}{|l|}{ State } \\
\hline Dry & 60.1 & -115.9 & 0.25 & 28.49 & $5.55 \mathrm{E}-88$ & 82.11 & 0.212 \\
\hline Saturated & -7.62 & 30.11 & 0.001 & 6.607 & 0 & 489.81 & - \\
\hline Frozen & 56.86 & -120.92 & 0.066 & 22.96 & $-3 .-1 \mathrm{E} 107$ & -99.81 & 0.055 \\
\hline
\end{tabular}

in diameter and 75 and $107.18 \mathrm{~mm}$ in height. Similarly, 42 samples were cut for the Brazilian test, but 36 tests were carried out. Figure 2 shows laboratory samples of marl, which are divided into three groups based on height for testing in dry, saturated, and frozen conditions. The U-named specimens were used for UCS test, and the B-named samples were used for Brazilian tensile test.

Finally, 48 samples were considered for the point load test (PLT). To perform the PLT, samples that were split in half in the Brazilian test were used; Therefore, these samples can be named half cut broken samples (Fig. 3a). The tests on frozen samples were made on water saturated rock samples cooled to $-20{ }^{\circ} \mathrm{C}$. The tests were made according to ISRM (1985, 2007) suggested methods. Point load test (PLT), which was first designed by Riechmuth (1963) and developed by Broch and Franklin (1972) to determine the point load strength index $\left(I_{\mathrm{S}}\right)$, is one of the oldest and most commonly used index tests for the determination of the UCS indirectly. The following equation is suggested by ISRM $(1985,2007)$ and ASTM (1995) for the calculation of $I_{S}$.

The point load test allows the determination of the uncorrected point load strength index $\left(I_{\mathrm{S}}\right)$. It must be corrected to the standard equivalent diameter (De) of $50 \mathrm{~mm}$. If the core being tested is "near" $50 \mathrm{~mm}$ in diameter (like NX-size core, $54.7 \mathrm{~mm}$ ), the correction is not necessary. The procedure for size correction can be obtained graphically or mathematically as outlined by the ISRM procedures.

$I_{\mathrm{S}}=\frac{P}{D_{\mathrm{e}}^{2}}, D_{\mathrm{e}}^{2}=\frac{4 h D}{\pi}, F=\left[\frac{D_{\mathrm{e}}}{50}\right]^{0.45}, I_{\mathrm{S}}(50)=F \times I_{\mathrm{S}}$

where $I_{\mathrm{S}}$, is the point load strength index in MPa, $P$ is the failure load in $\mathrm{kN}$, and De is the equivalent diameter in $\mathrm{mm}$. 
Fig. 6 Tensile strength of the marl as a function of density (dry, water saturated, and frozen)

Table 14 Tensile strength of marl as a function of density

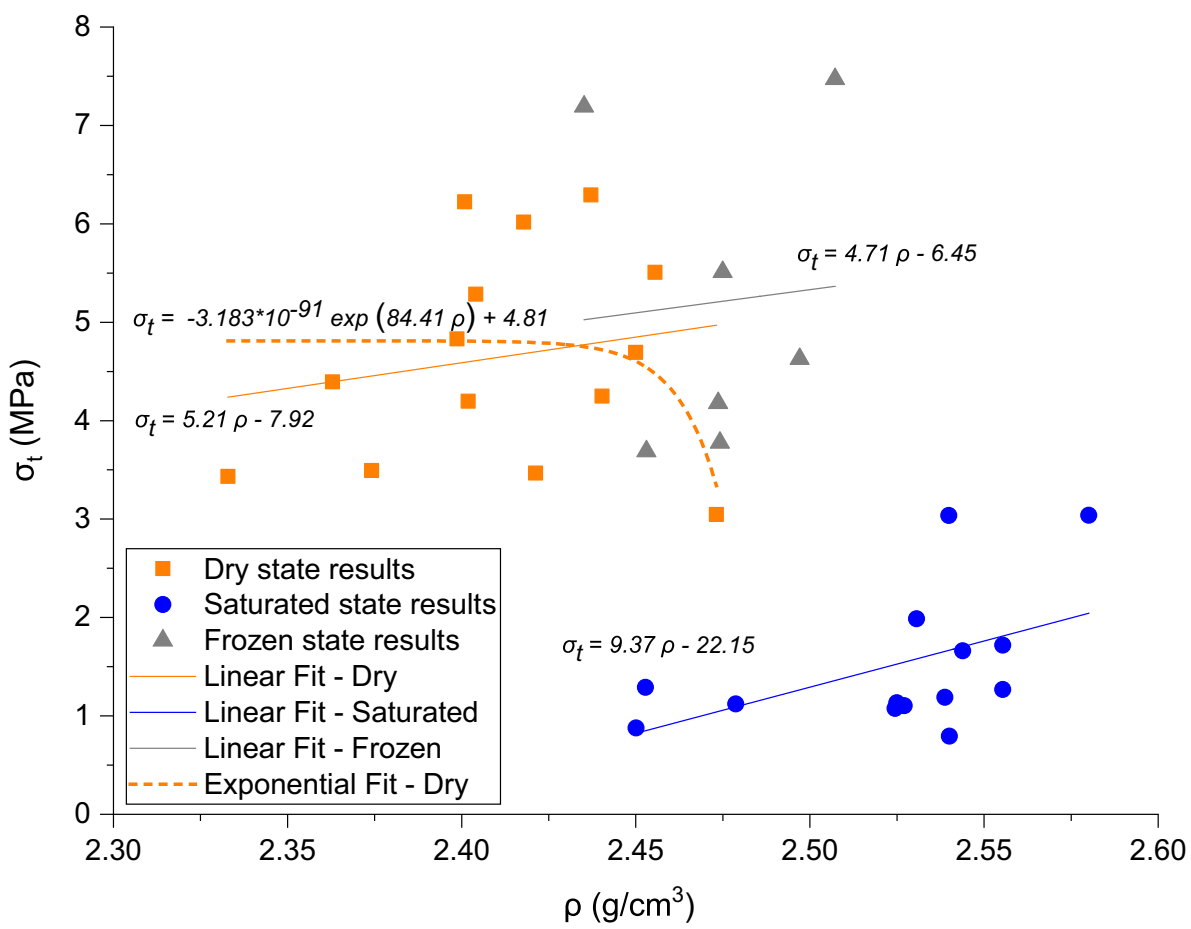

\begin{tabular}{|c|c|c|c|c|c|c|c|}
\hline \multirow{3}{*}{$\begin{array}{l}\text { Fitting function } \\
\text { Equation } \\
\text { Parameters }\end{array}$} & \multicolumn{3}{|c|}{ Linear } & \multicolumn{4}{|c|}{ Exponential } \\
\hline & \multicolumn{3}{|c|}{$\sigma_{\mathrm{t}}=a \rho+b$} & \multicolumn{4}{|c|}{$\sigma_{\mathrm{t}}=\sigma_{\mathrm{t} 0}+A \exp \left(R_{0} \rho\right)$} \\
\hline & $a$ & $b$ & $R^{2}$ & $\sigma_{\mathrm{c} 0}$ & $A$ & $R_{0}$ & $R^{2}$ \\
\hline \multicolumn{8}{|l|}{ State } \\
\hline Dry & 5.21 & -7.92 & 0.034 & 4.81 & $-3.18 \mathrm{E}-91$ & 84.41 & 0.212 \\
\hline Saturated & 9.37 & -22.15 & 0.25 & 0.878 & 0 & 336.8 & - \\
\hline Frozen & 4.71 & -6.45 & 0.005 & 7.19 & 0 & 403.87 & - \\
\hline
\end{tabular}

The point load test was carried out on half cut broken samples, as presented in Fig. $3 \mathrm{~b}$.

\section{Results}

The results of UCS and Brazilian tests are summarized in Tables 1, 2, 3, 4, 5, 6, 7, 8 and 9. A typical stress-strain curve of studied marl specimens is very different under dry, water saturated, and frozen conditions (Fig. 4). As it is evident, with the reduction of temperature, the compaction stage can be shortened, and the slope of the elastic stage increases, and then yield phenomenon becomes more and more unobvious, which means increases in elastic modulus and brittleness.
Based on above presented tables, the range of modulus of elasticity $(E)$ for dry samples is between 1.63 and $8.6 \mathrm{GPa}$ with the mean value of $3.83 \mathrm{GPa}$; for saturated samples is between 0.63 and $4.52 \mathrm{GPa}$ with the mean value of 2.36 $\mathrm{GPa}$, and for frozen samples is between 0.64 and $12.7 \mathrm{GPa}$ with the mean value of $2.74 \mathrm{GPa}$. The range of $M_{\mathrm{R}}$ for dry samples is between 61.37 and 229.2 , with the mean value of 126.7, for saturated samples is between 94.53 and 333.93 with the mean value of 193.83, and for frozen samples is between 35.89 and 312.49 with the mean value of 110.28. The range of $\sigma_{\mathrm{c}}$ for dry samples is in between 23.58 and 37.52 with the mean value of $29.62 \mathrm{MPa}$, and for saturated samples are between 4.64 and 19.5 with the mean value of 11.76 MPa and for frozen samples is between 9.90 and 40.65 with the mean value of $21.93 \mathrm{MPa}$. The results of PLT tests are summarized in Tables 10, 11, and 12. 
Fig. 7 Modulus of elasticity of the marl as a function of density (dry, water saturated, and frozen)
Table 15 Modulus of elasticity of marl as a function of density

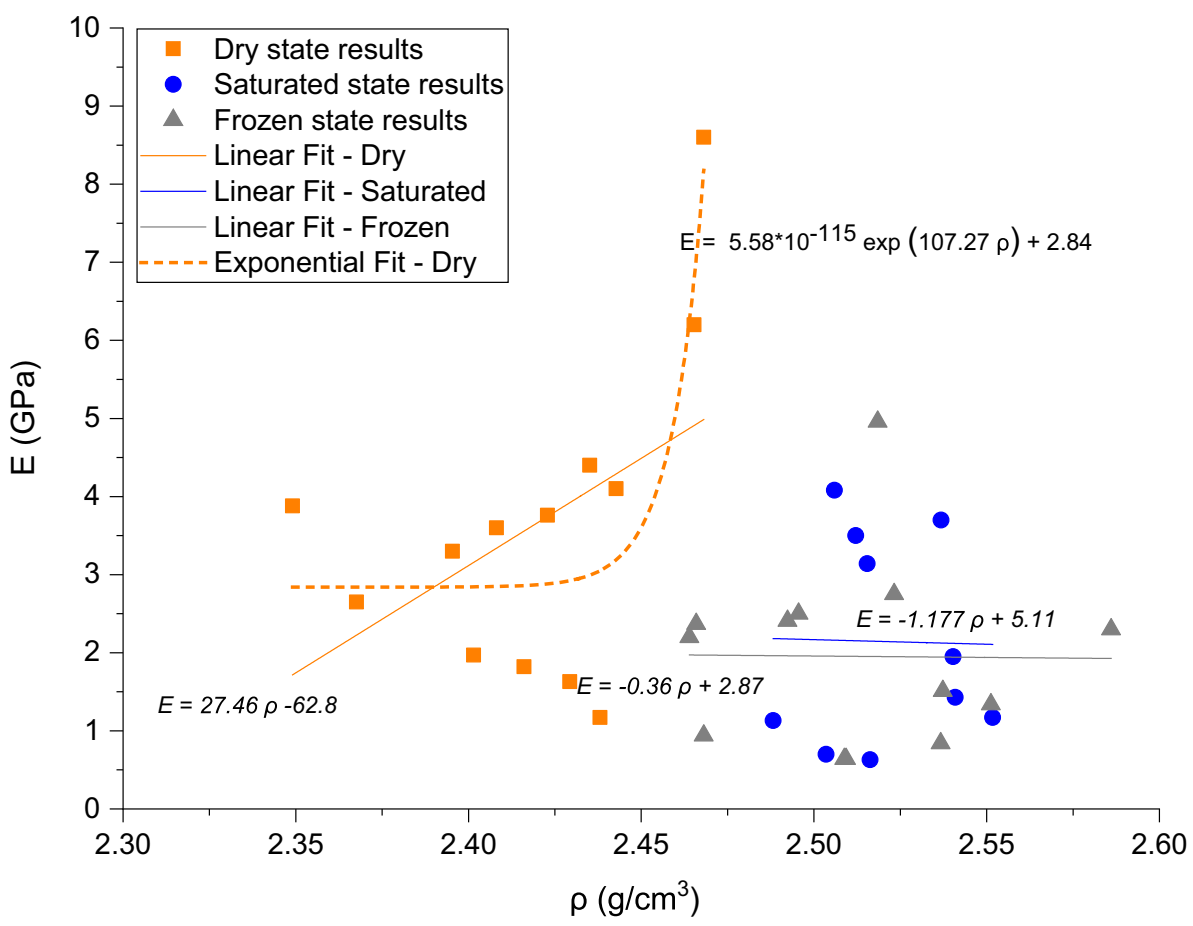

Through analyzing data, new linear and nonlinear correlations between density, uniaxial compressive strength $\left(\sigma_{\mathrm{c}}\right)$, tensile strength $\left(\sigma_{\mathrm{t}}\right)$, elasticity module, Modulus ratio $\left(M_{\mathrm{R}}\right)$, and $\left(\sigma_{\mathrm{c}} / \sigma_{\mathrm{t}}\right)$ have been established. Figure 5 illustrates the relationship between uniaxial compressive strength and density in dry, saturated, and frozen conditions. The correlation was weak in all dry, saturated and frozen conditions (see Table 13). Figure 6 exhibits the relationship between tensile strength and density in dry, saturated, and frozen conditions. The observed correlation is weak in all dry, saturated, and frozen conditions (see Table 14). In addition, Fig. 7 depicts the relationship between Young modulus and density in dry, saturated, and frozen conditions. Under dry condition, Nonlinear exponential correlation with coefficient of determination $\left(R^{2}=0.73\right)$ was observed. (see Table 15$)$. Figure 8 exhibits the relationship between $\left(\sigma_{\mathrm{c}} / \sigma_{\mathrm{t}}\right)$ and density in dry, saturated, and frozen conditions. Under dry condition, nonlinear exponential correlation with coefficient of determination $\left(R^{2}=0.73\right)$ was observed (see Table 16$)$.

Figure 9 demonstrates the relationship between uniaxial compressive strength and ultrasonic wave velocity $\left(V_{\mathrm{P}}\right)$. As shown, there is linear and nonlinear exponential correlation under saturated condition with coefficient of determination 
Fig. $8\left(\sigma_{\mathrm{c}} / \sigma_{\mathrm{t}}\right)$ of the marl as a function of density (dry, water saturated, and frozen)
Table $16\left(\sigma_{\mathrm{c}} / \sigma_{\mathrm{t}}\right)$ of marl as a function of density

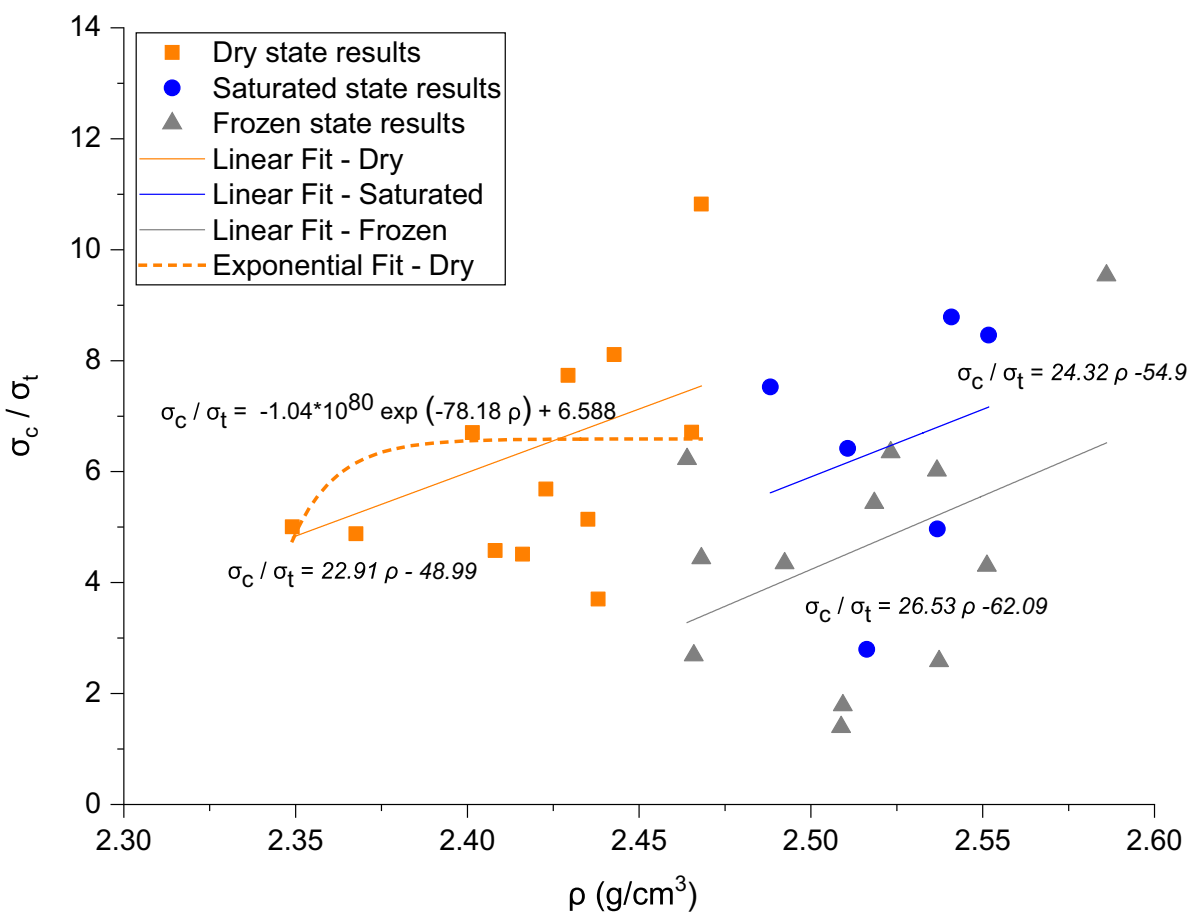

\begin{tabular}{|c|c|c|c|c|c|c|c|}
\hline \multirow{3}{*}{$\begin{array}{l}\text { Fitting function } \\
\text { Equation } \\
\text { Parameters }\end{array}$} & \multicolumn{3}{|c|}{ Linear } & \multicolumn{4}{|c|}{ Exponential } \\
\hline & \multicolumn{3}{|c|}{$\sigma_{\mathrm{c}} / \sigma_{\mathrm{t}}=a \rho+b$} & \multicolumn{4}{|c|}{$\sigma_{\mathrm{c}} / \sigma_{\mathrm{t}}=\left(\sigma_{\mathrm{c} 0} / \sigma_{\mathrm{t} 0}\right)+A \exp \left(R_{0} \rho\right)$} \\
\hline & $a$ & $b$ & $R^{2}$ & $\left(\sigma_{\mathrm{c} 0} / \sigma_{\mathrm{t} 0}\right)$ & $A$ & $R_{0}$ & $R^{2}$ \\
\hline \multicolumn{8}{|l|}{ State } \\
\hline Dry & 22.91 & -48.99 & 0.135 & 6.59 & $-1.05 \mathrm{E} 80$ & -78.18 & 0.736 \\
\hline Saturated & 24.32 & -54.9 & 0.062 & 6.4 & 0 & -140.1 & - \\
\hline Frozen & 26.53 & -62.09 & 0.18 & 4.59 & 0 & -217.38 & - \\
\hline
\end{tabular}

$\left(R^{2}=0.42\right)$ (see Table 17). Similarly, Fig. 10 shows the relationship between tensile strength and $V_{\mathrm{P}}$. As shown, there is linear and nonlinear exponential correlation under saturated condition with coefficient of determination $\left(R^{2}=0.53\right.$ and $R^{2}=0.59$ ), respectively (Table 18 ). Figure 11 shows the $\left(\sigma_{\mathrm{c}} / \sigma_{\mathrm{t}}\right)$ of marl as a function of $V_{\mathrm{p}}$. As shown, there is nonlinear exponential correlation under frozen condition with coefficient of determination $\left(R^{2}=0.72\right)$ (Table 19). Figure 12 shows the relationship between $M_{\mathrm{R}}$ and maximum axial strain. As shown, there is nonlinear exponential correlation under saturated condition with coefficient of determination $\left(R^{2}=0.88\right)$ (Table 20). Finally, Fig. 13 shows the relationship between uniaxial compressive strength and $I_{\mathrm{S}}(50)$. As shown, there is linear correlation under saturated and frozen conditions with coefficient of determination $\left(R^{2}=0.74\right.$ and $R^{2}=0.71$ ), respectively. Also, nonlinear exponential correlation under saturated and frozen conditions with coefficient of determination $\left(R^{2}=0.59\right.$ and $\left.R^{2}=0.88\right)$ was observed. (Table 21).

\section{Discussion}

The results of statistical analysis of uniaxial compressive strength and tensile strength, Young modulus, and $\left(\sigma_{\mathrm{c}} / \sigma_{\mathrm{t}}\right)$ of marl samples under dry, saturated, and frozen conditions 
Fig. 9 Uniaxial compressive strength of marl as a function of $V_{\mathrm{P}}$ (dry, water saturated, and frozen states)
Table 17 Uniaxial compressive strength of marl as a function of $V_{\mathrm{P}}$

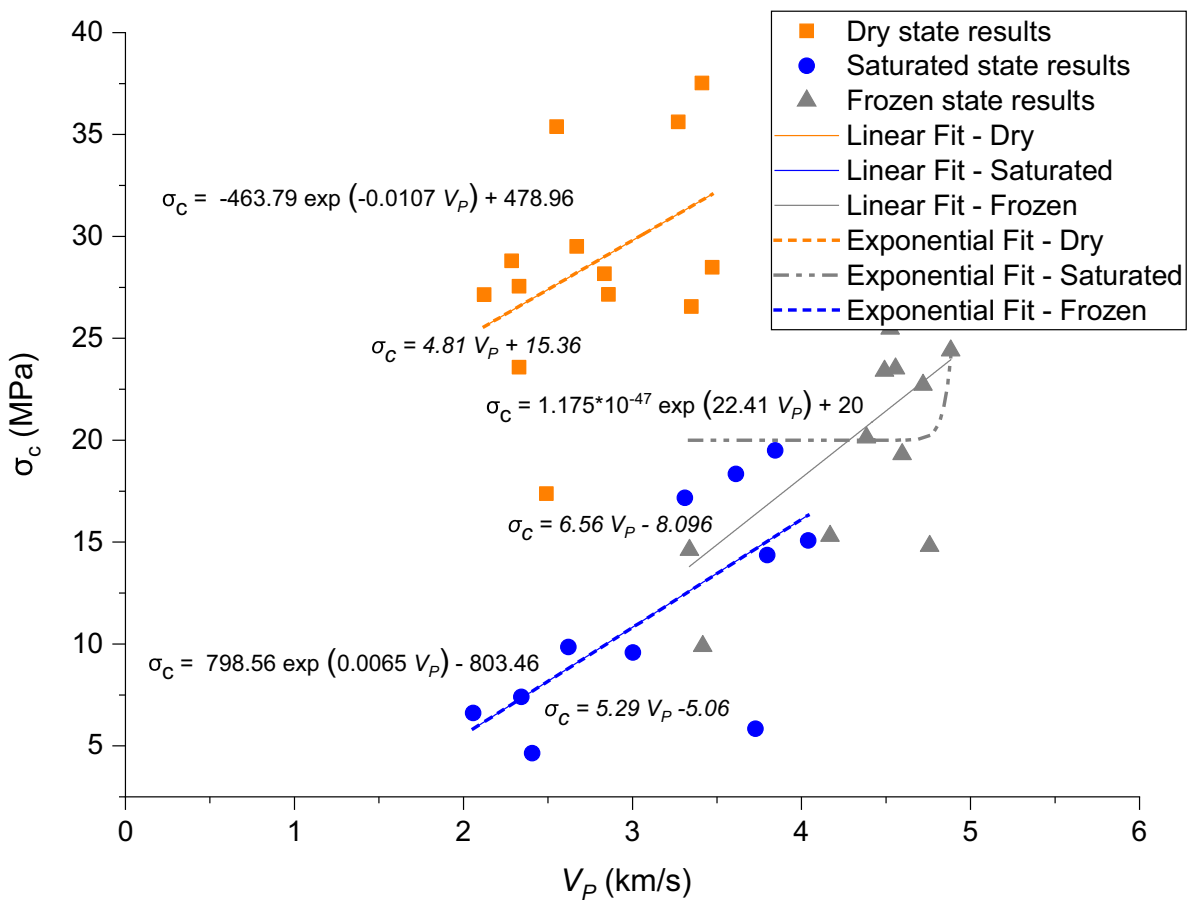

\begin{tabular}{|c|c|c|c|c|c|c|c|}
\hline \multirow{3}{*}{$\begin{array}{l}\text { Fitting function } \\
\text { Equation } \\
\text { Parameters }\end{array}$} & \multicolumn{3}{|c|}{ Linear } & \multicolumn{4}{|c|}{ Exponential } \\
\hline & \multicolumn{3}{|c|}{$\sigma_{\mathrm{c}}=a V_{\mathrm{P}}+b$} & \multicolumn{4}{|c|}{$\sigma_{\mathrm{c}}=\sigma_{\mathrm{c} 0}+A \exp \left(R_{0} V_{\mathrm{P}}\right)$} \\
\hline & $\bar{a}$ & $b$ & $R^{2}$ & $\overline{\sigma_{\mathrm{c} 0}}$ & $A$ & $R_{0}$ & $R^{2}$ \\
\hline \multicolumn{8}{|l|}{ State } \\
\hline Dry & 4.81 & 15.35 & 0.6 & 478.96 & -463.79 & -0.0107 & 0.185 \\
\hline Saturated & 5.29 & -5.06 & 0.48 & -803.46 & 798.56 & 0.0065 & 0.48 \\
\hline Frozen & 6.56 & -8.09 & 0.31 & 20 & $1.175 \mathrm{E}-47$ & 22.42 & 0.041 \\
\hline
\end{tabular}

are presented in Tables $1,2,3,4,5,6$, and 7 . The average maximum uniaxial compressive strength in the frozen condition is $21.93 \mathrm{MPa}$, which is $86 \%$ more than saturated ones (11.76 MPa). Similarly, (Török et al. 2018) examined the effect of freezing on the strength of porous limestone and observed the strength of the frozen saturated limestone is more than $50 \%$ than that of the saturated one. Davarpanah et al. (2019), carried out similar research on highly porous limestone and observed an $80 \%$ increase in strength due to freezing. However, The average modulus of elasticity in frozen condition for studied marl samples is 2.74 which is $16 \%$ more than saturated condition. The increase in modulus of elasticity due to freezing is not notable compare to the strength properties. The reason is associated with the presence of clay minerals and their variation in marl samples.
Similarly, based on our current measurement on marl, the strength increase due to freezing is $86 \%$. Also, the average maximum uniaxial compressive strength in the dry condition is $29.62 \mathrm{MPa}$, which is about $60 \%$ more than saturated ones $(11.76 \mathrm{MPa})$. This result is in good agreement with the published result by (Vásárhelyi 2005) for Miocene Limestone, which showed a $60 \%$ loss in strength due to saturation. According to the results, as temperature decreases, the strength parameters of rock increase. This phenomenon is in accordance with the obtained results by Maoyan et al. (2020).

Furthermore, the correlation between Ultrasonic wave velocity $\left(V_{\mathrm{P}}\right)$ and UCS has been studied by different authors (Turgrul and Zarif 1999; Cobanoglu and Celik 2008; Sharma and Singh 2008; Diamantis et al. 2011; Sarkar et al. 2012; 
Fig. 10 Tensile strength of marl as a function of $V_{\mathrm{P}}$ (dry, water saturated, and frozen states)
Table 18 Tensile strength of marl as a function of $V_{P}$

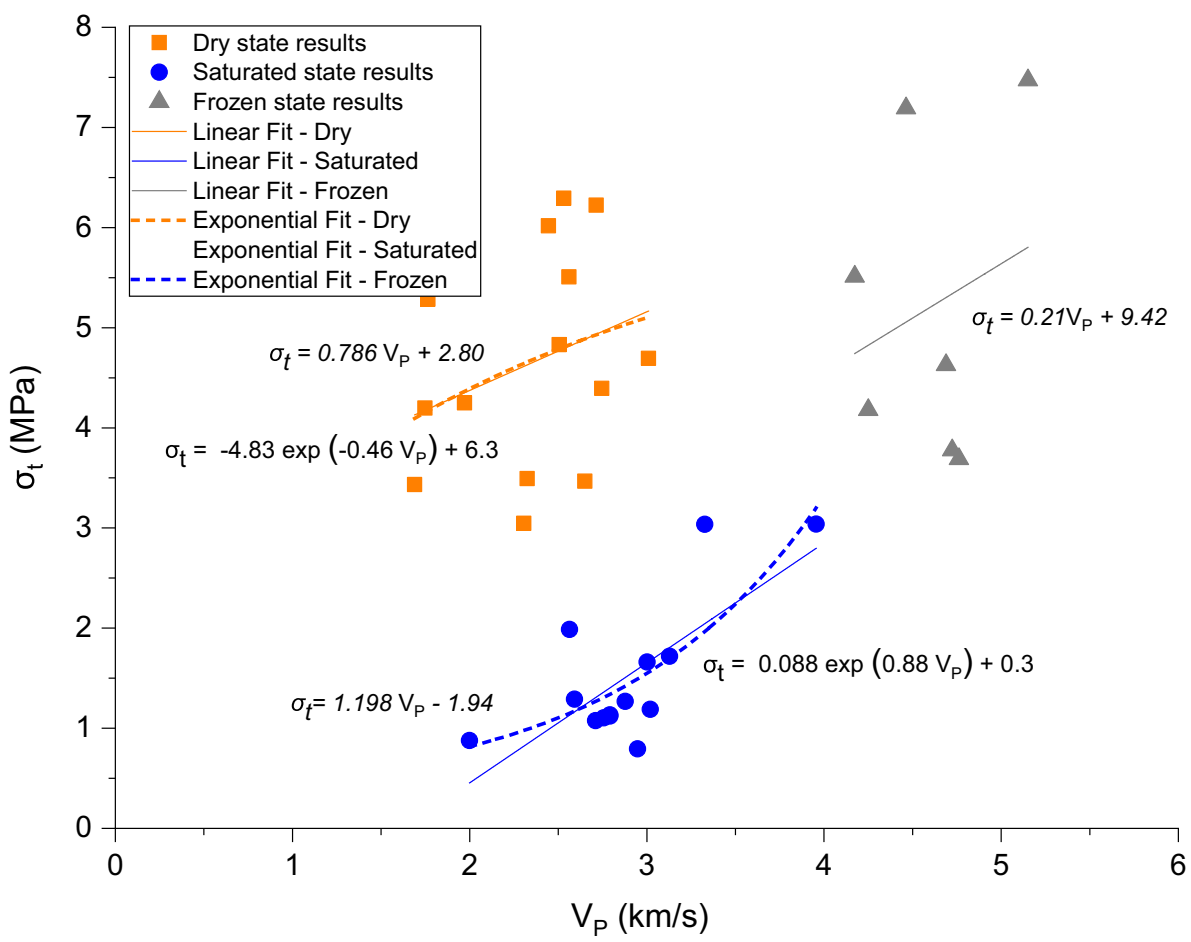

\begin{tabular}{|c|c|c|c|c|c|c|c|}
\hline \multirow{3}{*}{$\begin{array}{l}\text { Fitting function } \\
\text { Equation } \\
\text { Parameters }\end{array}$} & \multicolumn{3}{|l|}{ Linear } & \multicolumn{4}{|c|}{ Exponential } \\
\hline & \multicolumn{3}{|c|}{$\sigma_{\mathrm{t}}=a V_{\mathrm{P}}+b$} & \multicolumn{4}{|c|}{$\sigma_{\mathrm{t}}=\sigma_{\mathrm{t} 0}+A \exp \left(R_{0} V_{\mathrm{P}}\right)$} \\
\hline & $\bar{a}$ & $b$ & $R^{2}$ & $\overline{\sigma_{\mathrm{t} 0}}$ & $A$ & $R_{0}$ & $R^{2}$ \\
\hline \multicolumn{8}{|l|}{ State } \\
\hline Dry & 0.78 & 2.8 & 0.09 & 6.3 & -4.83 & -0.46 & 0.09 \\
\hline Saturated & 1.197 & -1.94 & 0.53 & 0.3 & 0.088 & 0.88 & 0.59 \\
\hline Frozen & 1.085 & 0.21 & 0.054 & 5.2 & 0 & $-1.42 \mathrm{E} 13$ & - \\
\hline
\end{tabular}

Khandelwal 2013; Azimian and Ajalloeian 2015; Kahraman 2001; Yasar and Erdogan 2004; Kilic and Teymen 2008; Yagiz 2011; Jamshidi et al. 2016) presented in (Table 22). The difference in $R^{2}$ value obtained in our study and given by other researchers in Table 22 is thought to be due to the difference in the range of physical and mechanical properties of the tested rock types. However, if we focus on proposed linear correlations as formulated $(y=a x+b)$, an interesting correlation between $\mathrm{a}$ and $\mathrm{b}$ constant with a high determination coefficient $R^{2}$ is notable (Fig. 14). It means that the uniaxial compressive strength $\left(\sigma_{\mathrm{c}}\right)$ depends on the $V_{\mathrm{P}}$ only with a one-parameter formula: $\sigma_{\mathrm{c}}=a V_{\mathrm{p}}+b$

where $b$ is rock type dependent parameter.

Based on our measurements, a linear correlation between uniaxial compressive strength and $I_{S}(50)$ was observed in saturated, and frozen conditions with a determination coefficient $\left(R^{2}=0.74\right.$ and $\left.R^{2}=71\right)$, respectively. Also, nonlinear exponential correlation with a determination coefficient $\left(R^{2}=0.88\right)$ was observed under frozen condition. Our findings are in agreement with the published results by Şahin et al. (2020) for different rock types such as basalt, limestone, marble, andesite, sandstone, and granite with a determination coefficient of 0.9 . Our results are also in good 
Fig. $11\left(\sigma_{\mathrm{c}} / \sigma_{\mathrm{t}}\right)$ of marl as a function of $V_{\mathrm{P}}$ (dry, water saturated, and frozen states)
Table $19\left(\sigma_{\mathrm{c}} / \sigma_{\mathrm{t}}\right)$ of marl as a function of $V_{\mathrm{P}}$

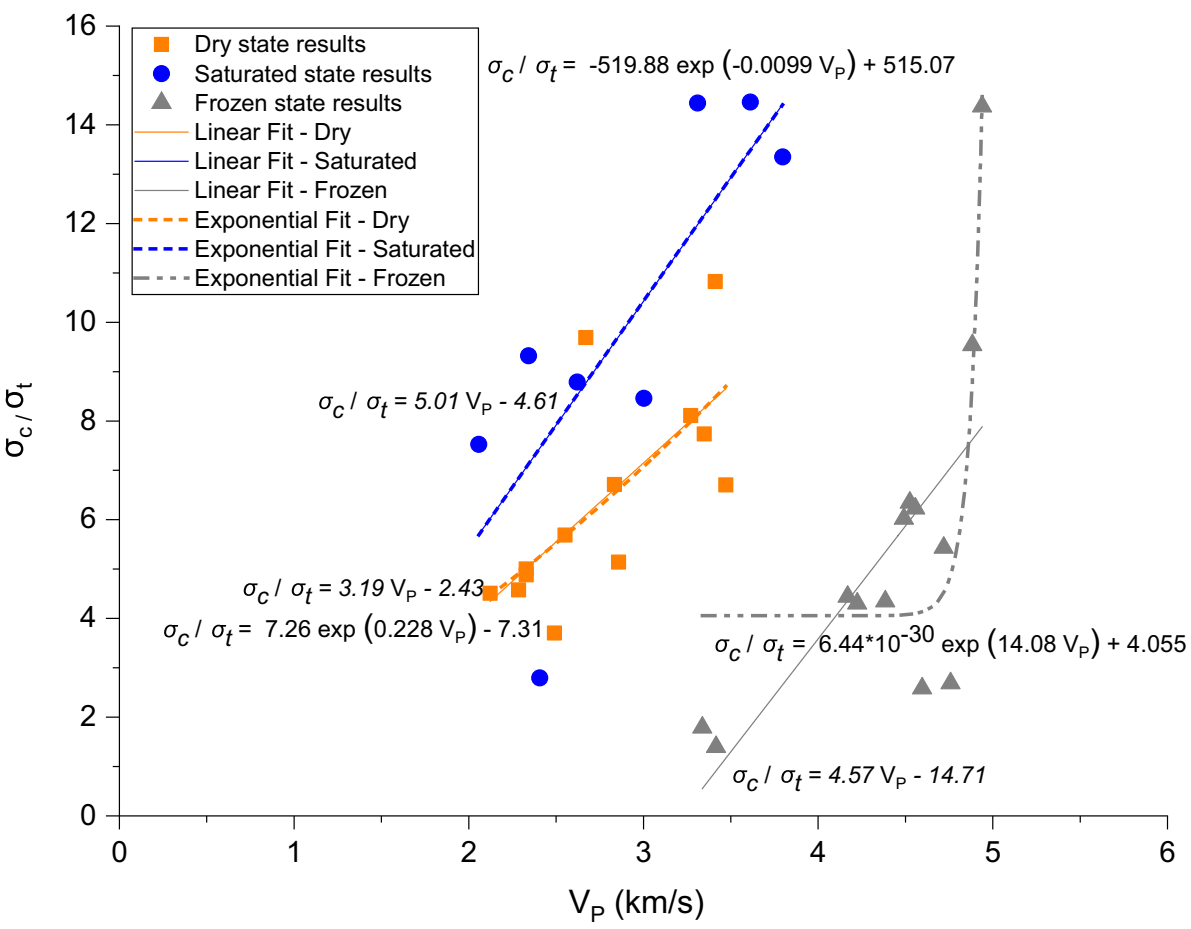

\begin{tabular}{|c|c|c|c|c|c|c|c|}
\hline \multirow{3}{*}{$\begin{array}{l}\text { Fitting function } \\
\text { Equation } \\
\text { Parameters }\end{array}$} & \multirow{2}{*}{\multicolumn{3}{|c|}{$\frac{\text { Linear }}{\sigma_{\mathrm{c}} / \sigma_{\mathrm{t}}=a V_{\mathrm{P}}+b}$}} & \multirow{2}{*}{\multicolumn{4}{|c|}{$\begin{array}{l}\text { Exponential } \\
\sigma_{\mathrm{c}} / \sigma_{\mathrm{t}}=\left(\sigma_{\mathrm{c} 0} / \sigma_{\mathrm{t} 0}\right)+A \exp \left(R_{0} V_{\mathrm{P}}\right)\end{array}$}} \\
\hline & & & & & & & \\
\hline & $a$ & $b$ & $R^{2}$ & $\left(\sigma_{\mathrm{c} 0} / \sigma_{\mathrm{t} 0}\right)$ & $A$ & $R_{0}$ & $R^{2}$ \\
\hline \multicolumn{8}{|l|}{ State } \\
\hline Dry & 3.19 & -2.43 & 0.49 & -7.31 & 7.26 & 0.228 & 0.49 \\
\hline Saturated & 5.01 & -4.61 & 0.63 & 515 & -519.89 & -0.0099 & 0.63 \\
\hline Frozen & 4.57 & -14.71 & 0.43 & 4.05 & $6.44 \mathrm{E}-30$ & 14.08 & 0.72 \\
\hline
\end{tabular}

accordance with the published data by Heidari et al. (2012) for gypsum rock in dry and saturated conditions with a determination coefficient of 0.94 and 0.93 , respectively.

\section{Conclusion}

The laboratory tests were performed to provide more insight into critical mechanical properties of Hungarian marl samples such as uniaxial compressive strength (UCS), Brazilian tensile test, ultrasonic wave velocity, and point load test (PLT) under dry, saturated, and frozen condition. Also, based on our analyses, new correlations were developed between these properties. The following conclusions have been drawn:

- An average uniaxial compressive strength of frozen samples is $21.93 \mathrm{MPa}$, which is $86 \%$ more than saturated ones $(11.76 \mathrm{MPa})$. Under freezing conditions, the cementation of the ice and particles improves the integrity of the rock mass, making the rock viscoplastic and brittle. Moreover, the strength of rock mass is thought to increase in frozen rock because of the increase in the fracture initiation stress, which follows the elastic defor- 
Fig. $12 M_{\mathrm{R}}$ of marl as a function of strain (dry, water saturated, and frozen states)
Table $20 M_{R}$ of marl as a function of strain

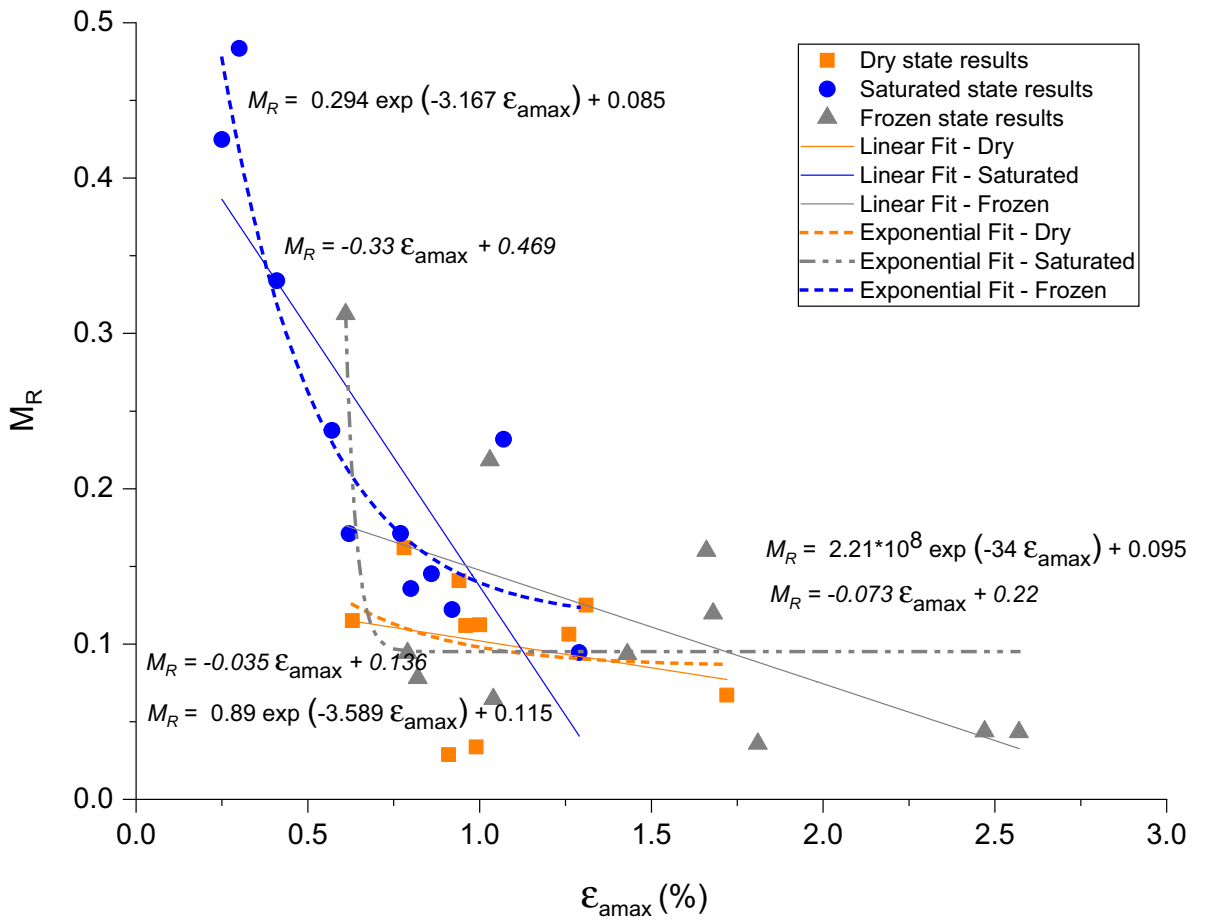

\begin{tabular}{|c|c|c|c|c|c|c|c|}
\hline \multirow{3}{*}{$\begin{array}{l}\text { Fitting function } \\
\text { Equation } \\
\text { Parameters }\end{array}$} & \multicolumn{3}{|l|}{ Linear } & \multicolumn{4}{|c|}{ Exponential } \\
\hline & \multicolumn{3}{|c|}{$M_{\mathrm{R}}=a \varepsilon_{\mathrm{amax}}+b$} & \multicolumn{4}{|c|}{$M_{\mathrm{R}}=M_{\mathrm{R} 0}+A \exp \left(R_{0} \varepsilon_{\mathrm{amax}}\right)$} \\
\hline & $a$ & $b$ & $R^{2}$ & $M_{\mathrm{R} 0}$ & $A$ & $R_{0}$ & $R^{2}$ \\
\hline \multicolumn{8}{|l|}{ State } \\
\hline Dry & -0.035 & 0.136 & 0.059 & 0.086 & 0.294 & -3.167 & 0.065 \\
\hline Saturated & -0.33 & 0.47 & 0.7 & 0.115 & 0.89 & -3.59 & 0.88 \\
\hline Frozen & -0.073 & 0.22 & 0.33 & 0.095 & $2.21 \mathrm{E} 8$ & -34 & 0.59 \\
\hline
\end{tabular}

mation region, due to a reduction in the stress concentration in the pores or interstitial spaces within the rock.

- The average tensile strength of frozen samples is $4.98 \mathrm{MPa}$, which is $219 \%$ more than saturated ones (1.56 MPa). So, the gain in strength in tensile strength is 2.5 times more than gain in strength in uniaxial compressive strength. The reason is that the reduction in stress concentration in tension was found to be more than in compression hence contributing to greater increases in tensile strength than that found in compressive strength.

- An average Young modulus of frozen samples is 2.74 $\mathrm{GPa}$, which is $13 \%$ more than saturated ones $(2.36 \mathrm{GPa})$.

- An average $\left(\sigma_{\mathrm{c}} / \sigma_{\mathrm{t}}\right)$ of frozen samples is 5.35 , which is $26 \%$ less than saturated ones 6.74 .

- An average maximum axial failure strain of frozen samples is $1.37 \%$, which is about $50 \%$ more than saturated ones $(0.71 \%)$.

- An average modulus ratio of frozen samples is 110.28 , which is $75 \%$ less than saturated ones (193.83).
- Interestingly, a good correlation was observed between uniaxial compressive strength (UCS) and $V_{\mathrm{P}}$ under the dry condition with a determination coefficient of 0.6 . This correlation, notwithstanding, was week under saturated and frozen conditions.

- Considering the relationship between UCS and $I_{S}(50)$, a good correlation observed under dry and frozen conditions with the determination coefficient of 0.8 and 0.7 , respectively.

- Although there was a good correlation between $M_{\mathrm{R}}$ and maximum axial strain in saturated condition with the determination coefficient of 0.8 , the observed correlation under dry and frozen conditions was not remarkable.

- Based on the $\left(\sigma_{\mathrm{c}} / \sigma_{\mathrm{t}}\right)$ of examined samples, a good correlation was established between the $\left(\sigma_{\mathrm{c}} / \sigma_{\mathrm{t}}\right)$ and $V_{\mathrm{P}}(\mathrm{km} / \mathrm{s})$ under dry and frozen conditions with a determination coefficient of 0.7 and 0.6 , respectively. Nevertheless, with much surprise, this correlation was not notable in saturated condition. 
Fig. 13 Relationship between UCS and $I_{\mathrm{S}}(50)$ (dry, water saturated, and frozen states)

Table 21 Uniaxial compressive strength as a function of $\mathrm{I}_{\mathrm{S}}(50)$

Table 22 Previously published linear regression between UCS and $V_{\mathrm{P}}$ for different rock types in dry condition

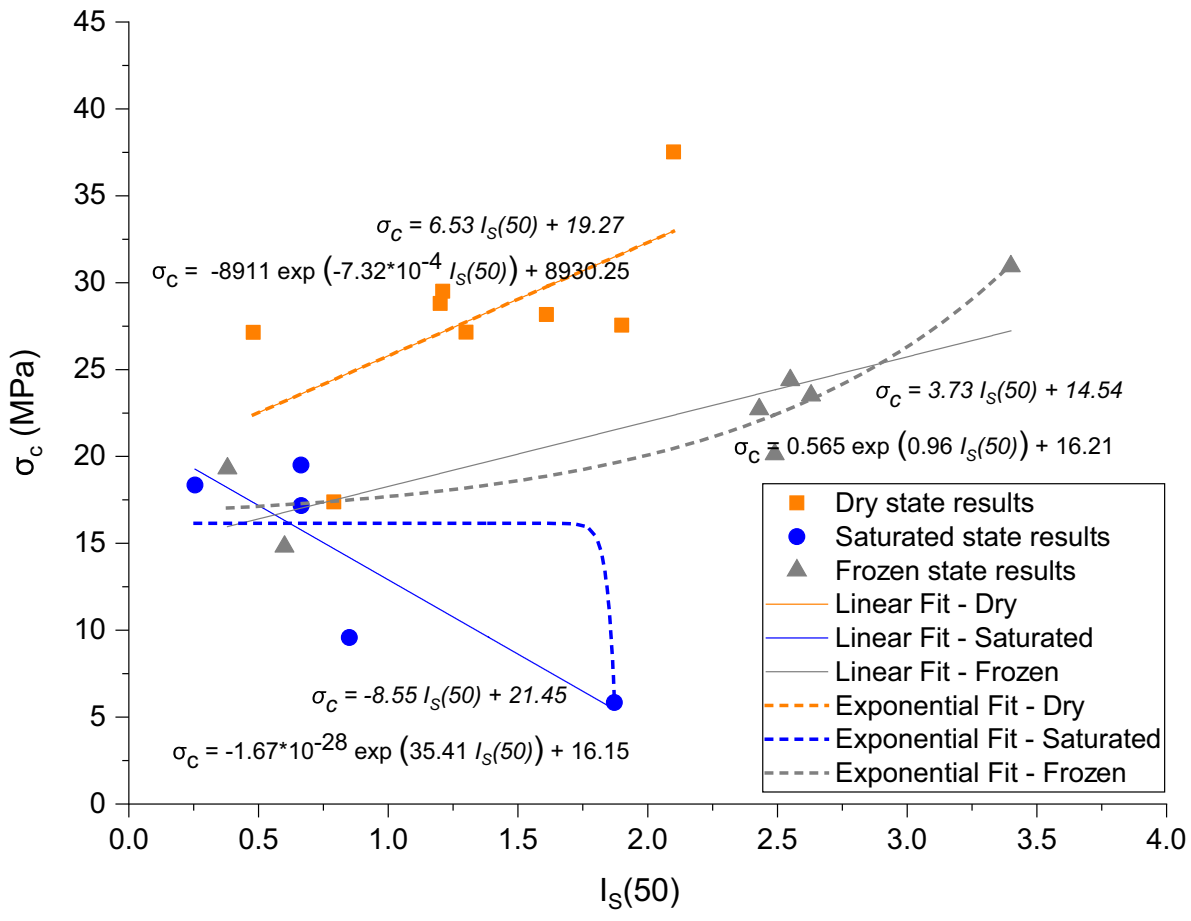

\begin{tabular}{|c|c|c|c|c|c|c|c|}
\hline \multirow{3}{*}{$\begin{array}{l}\text { Fitting function } \\
\text { Equation } \\
\text { Parameters }\end{array}$} & \multirow{2}{*}{\multicolumn{3}{|c|}{$\begin{array}{l}\text { Linear } \\
\sigma_{\mathrm{c}}=a I_{\mathrm{S}}(50)+b\end{array}$}} & \multirow{2}{*}{\multicolumn{4}{|c|}{$\begin{array}{l}\text { Exponential } \\
\sigma_{\mathrm{c}}=\sigma_{\mathrm{c} 0}+A \exp \left(R_{0} I_{\mathrm{S}}(50)\right)\end{array}$}} \\
\hline & & & & & & & \\
\hline & $a$ & $b$ & $R^{2}$ & $\sigma_{\mathrm{c} 0}$ & $A$ & $R_{0}$ & $R^{2}$ \\
\hline \multicolumn{8}{|l|}{ State } \\
\hline Dry & 6.52 & 19.26 & 0.42 & 8930.25 & -8911 & $-7.33 \mathrm{E}-4$ & 0.42 \\
\hline Saturated & -8.55 & 21.45 & 0.74 & 16.15 & $-1.67 \mathrm{E}-28$ & 35.41 & 0.59 \\
\hline Frozen & 3.73 & 14.54 & 0.71 & 16.22 & 0.56 & 0.96 & 0.88 \\
\hline
\end{tabular}

\begin{tabular}{|c|c|c|c|c|}
\hline Rock type & $a$ & $b$ & $R^{2}$ & Author \\
\hline Igneous rocks & 35.54 & 55 & 0.80 & Turgrul and Zarif (1999) \\
\hline $\begin{array}{l}\text { Sandstone, limestone, } \\
\text { and cement mortar }\end{array}$ & 56.71 & 192.93 & 0.67 & Cobanoglu and Celik (2008) \\
\hline $\begin{array}{l}\text { Sedimentary, metamor- } \\
\text { phic, and igneous rocks }\end{array}$ & 64.2 & 117.99 & 0.90 & Sharma and Singh (2008) \\
\hline Peridotites & 140 & 899.33 & 0.83 & Diamantis et al. (2011) \\
\hline Different rocks & 38 & 50 & 0.93 & Sarkar et al. (2012) \\
\hline Different rocks & 33 & 34.83 & 0.87 & Khandelwal (2013) \\
\hline Marly rocks & 26 & 20.47 & 0.91 & $\begin{array}{l}\text { Azimian and Ajalloeian } \\
\text { (2015) }\end{array}$ \\
\hline Travertine & 27.4 & 62.78 & 0.80 & Jamshidi et al. (2016) \\
\hline Marl & 19.23 & 19.91 & 0.60 & Present study \\
\hline
\end{tabular}


Fig. 14 Correlation between $a$ and $b$ constants of the linear regression of UCS- $V_{P}$ under dry condition

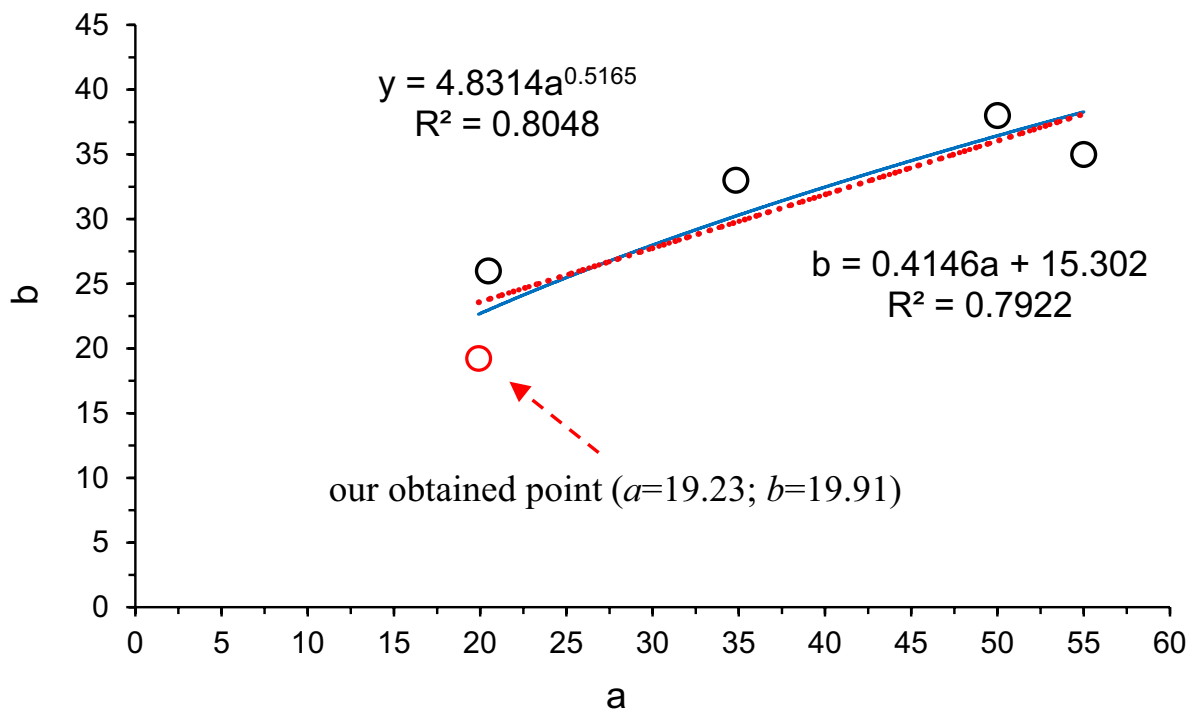

Acknowledgements The authors would like to sincerely thank all the colleagues and friends for their motivation and encouragement during this research. Their valuable and constructive comments are highly appreciated. In additioan, National Research and Development and Innovation Fund Program no. TKP 2020-BME-IKA-VIZ.

Funding Open access funding provided by Budapest University of Technology and Economics.

\section{Declaration}

Conflict of interest The authors declare that no conflict of interest exists in the submission of this manuscript, and the manuscript is approved by all authors for publication. All the authors listed have approved the manuscript that is enclosed.

Open Access This article is licensed under a Creative Commons Attribution 4.0 International License, which permits use, sharing, adaptation, distribution and reproduction in any medium or format, as long as you give appropriate credit to the original author(s) and the source, provide a link to the Creative Commons licence, and indicate if changes were made. The images or other third party material in this article are included in the article's Creative Commons licence, unless indicated otherwise in a credit line to the material. If material is not included in the article's Creative Commons licence and your intended use is not permitted by statutory regulation or exceeds the permitted use, you will need to obtain permission directly from the copyright holder. To view a copy of this licence, visit http://creativecommons.org/licenses/by/4.0/.

\section{References}

ASTM (1995) Standard method of test for elastic moduli of rock core specimens in uniaxial compression. American Society for Testing and Materials

Azimian A, Ajalloeian R (2015) Empirical correlation of physical and mechanical properties of marly rocks with $\mathrm{P}$ wave velocity. Arab J Geosci 8:2069-2079
Bar N, Barton N (2021) Q-Slope addressing ice wedging and freezethaw effects in Arctic and Alpine environments. In: ISRM international symposium Eurock 2020 — hard rock engineering Trondheim, Norway

Broch E, Franklin JA (1972) The point-load strength test. Int J Rock Mech Min Sci 9:669-697. https://doi.org/10.1016/0148-9062(72) 90030-7

Cobanoglu I, Celik SB (2008) Estimation of uniaxial compressive strength from point load strength, Schmidt hardness and P-wave velocity. Bull Eng Geol Environ 67:491-498

Davarpanah M, Ahmadi M, Török Á, Vásárhelyi B (2019) Investigation of the mechanical properties of dry, saturated and frozen highly porous limestone. In: 14th international congress on rock mechanics and rock engineering, ISRM 2019, Foz do Iguaçu, Brazil

Diamantis K, Bellas S, Migiros G, Gartzos E (2011) Correlating wave velocities with physical, mechanical properties and petrographic characteristics of peridotites from the central Greece. Geotech Geol Eng 29:1049-1062

Görög P (2007) Characterization and mechanical properties of the Eocene Buda Marl. Central Eur Geol 50(3):241-258

Heidari M, Khanlari GR, Torabi Kaveh M, Kargarian S (2012) Predicting the uniaxial compressive and tensile strengths of gypsum rock by point load testing. Rock Mech Rock Eng 45:265-273

ISRM (1985) Suggested method for determining point load strength. Int J Rock Mech Min Sci Geomech Abstr 22(2):51-60

ISRM (2007) The complete ISRM suggested methods for rock characterization, testing and monitoring: 1974-2006. In: Ulusay R, Hudson JA (eds) Compilation arranged by the ISRM Turkish National Group. Kozan Ofset, Ankara

Jamshidi A (2019) Reply to the discussion by Saffet Yagiz on "The effect of density and porosity on the correlation between uniaxial compressive strength and P-wave velocity.” Rock Mech Rock Eng 52:639-640

Jamshidi A, Nikudel MR, Khamehchiyan M, Zarei Sahamieh R (2016) The effect of specimen diameter size on uniaxial compressive strength, P-wave velocity and the correlation between them. Geomech Geoeng Int J 11(1):13-19

Jamshidi A, Zamanian H, Zarei S (2018) The Effect of density and porosity on the correlation between uniaxial compressive strength and P-wave velocity. Rock Mech Rock Eng 51:1279-1286

Jia H, Zi F, Yang G, Li G, Shen Y, Sun Q, Yang P (2020) Influence of pore water (ice) content on the strength and deformability 
of frozen argillaceous siltstone. Rock Mech and Rock Eng 53:967-974

Kahraman S (2001) Evaluation of simple methods for assessing the uniaxial compressive strength of rock. Int J Rock Mech Min Sci 38:981-994

Khandelwal M (2013) Correlating P-wave velocity with the physicomechanical properties of different rocks. Pure Appl Geophys 170:507-514

Kilic A, Teymen A (2008) Determination of mechanical properties of rocks using simple methods. Bull Eng Geol Environ 67:237-244

Kodama J, Goto T, Fujii Y, Hagan P (2013) The effects of water content, temperature and loading rate on strength and failure process of frozen rocks. Int J Rock Mech Min Sci 62:1-13

Kodama J, Mitsui Y, Hara S, Fukuda D, Fujii Y, Sainoki A, Karakus M (2019) Time-dependence of mechanical behavior of Shikotsu welded tuff at sub-zero temperatures. Cold Reg Sci Technol 168:102868

Li Z, Liu S, Ren W, Fang J, Zhu J, Dun Z (2020) Multiscale laboratory study and numerical analysis of water-weakening effect on shale. Hindawi Adv Mater Sci Eng. https://doi.org/10.1155/2020/ 5263431

Liu B, Ma YJ, Zhang G, Xu W (2018) Acoustic emission investigation of hydraulic and mechanical characteristics of muddy sandstone experienced one freeze-thaw cycle. Cold Reg Sci Technol 151:335-344

Liu B, Sun Y, Wang J, Zhang G (2020) Characteristic analysis of crack initiation and crack damage stress of sandstone and mudstone under low-temperature condition. J Cold Reg Eng. https://doi.org/ 10.1061/(ASCE)CR.1943-5495.0000225

Maoyan Ma, Yishun H, Guangyong C, Jian L, Shiliang Xu (2020) Study on mechanical behavior of jurassic frozen sandstone in western china based on NMR porosity. Hindawi. https://doi.org/ $10.1155 / 2020 / 2936932$

Mellor M (1971) Strength and deformability of rocks at low temperatures. USA Cold Regions Research and Engineering Laboratory, Research Report 294

Mellor M (1973) Mechanical properties of rocks at low temperatures. In: Permafrost: the North American contribution to the 2nd international conference on permafrost, Yakutsk, 13-28 July, Natural Academy of Sciences, Washington, DC

Miščević P, Vlastelica G (2011) Durability characterization of marls from the region of Dalmatia. Croatia Geotech Geol Eng 29(5):771-781. https://doi.org/10.1007/s10706-011-9416-y

Riechmuth DR (1963) Correlation of force-displacement data with physical properties of rock for percussive drilling systems. In: Proceedings of the 5th symposium on rock mechanics, pp 33-59
Roworth RM (2005) Understanding the effect of freezing on rock mass behavior as applied to the Cigar lakemining method. The University of Waterloo

Şahin M, Ulusay R, Karakul H (2020) Point load strength index of half-cut core specimens and correlation with uniaxial compressive strength. Rock Mech Rock Eng 53:3745-3760

Sarkar K, Vishal V, Singh TN (2012) An empirical correlation of index geomechanical parameters with the compressional wave velocity. Geotech Geol Eng 30:469-479

Sharma PK, Singh TN (2008) A correlation between P-wave velocity, impact strength index, slake durability index and uniaxial compressive strength. Bull Eng Geol Environ 67:17-22

Török Á, Ficsor A, Davarpanah M, Vásárhelyi B (2018) Comparison of mechanical properties of dry, saturated and frozen porous rocks. IAEG/AEG Ann Meet Proc San Francisco Calif 6:113-118

Turgrul A, Zarif IH (1999) Correlation of mineralogical and textural characteristics with engineering properties of selected granitic rocks from Turkey. Eng Geol 51:303-317

Vásárhelyi B (2005) Statistical analysis of the influence of water content on the strength of the Miocene Limestone. Rock Mech Rock Eng 38:69-76

Vásárhelyi B, Davarpanah M (2018) Influence of water content on the mechanical parameters of the intact rock and rock mass. Period Polytech Civ Eng 62:1060-1066

Vásárhelyi B, Ván P (2006) Influence of the water content for the strength of the rock. Eng Geol 84:70-74

Vlastelica G, Miščević P, Cvitanović NP (2018) Durability of soft rocks in Eocene flysch formation (Dalmatia, Croatia). Eng Geol 245:207-217. https://doi.org/10.1016/j.enggeo.2018.08.015

Wong LNY, Maruvanchery V, Liu G (2016) Water effects on rock strength and stiffness degradation. Acta Geotech 11(4):713-737. https://doi.org/10.1007/s11440-015-0407-7

Yagiz S (2011) P-wave velocity test for the assessment of some geotechnical properties of rock materials. Bull Mater Sci 34:943-957

Yagiz S (2019) Comments on: The effects of density and porosity on the correlation between uniaxial compressive strength and P-wave velocity by Amin Jamshidi, Hasan Zamanian, Reza Zarei Sahamieh, Rock Mechanics and Rock Engineering (2018) 51:1279-1286. Rock Mech Rock Eng 52:635-638

Yasar E, Erdogan Y (2004) Correlating sound velocity with the density, compressive strength and Young's modulus of carbonate rocks. Int J Rock Mech Min Sci 41:871-875 